\title{
Formation of Holocene sedimentary laminae in the Black Sea and the role of the benthic flocculent layer
}

\author{
Cynthia H. Pilskaln \\ School of Marine Sciences, University of Maine, Orono \\ Jennifer Pike \\ Department of Earth Sciences, University of Wales, Cardiff, Wales, United Kingdom
}

\begin{abstract}
Holocene Black Sea sediments recovered in 1988 and 1993 from box cores and gravity cores were analyzed geochemically, microscopically, and with backscattered electron imagery (BSEI) in order to determine the temporal, geochemical, and sedimentological relationships between the benthic flocculent layer (often referred to as the fluff layer) and the formation of underlying laminated unit I sediments. Existence of a permanent benthic fluff layer in the Black Sea basin is suggested, acting as a geochemical transition layer within which all sedimentary particles are hydraulically sorted and particles subject to dissolution or organic remineralization are altered prior to accumulation. We propose that particle residence time within the benthic fluff layer is a key factor in determining sedimentary microfabric and geochemical composition of laminated unit I sediments. We present a schematic model depicting the above relationships and use it to propose a paleoflux scenario for laminae formation in the unit II sapropel.
\end{abstract}

\section{Introduction}

The Black Sea is the largest anoxic body of water in the world, with waters below 100-200 m defined as sulfidic [Deuser, 1970; Murray et al., 1989; Millero, 1991; Murray et al., 1991]. During the last glaciation and earliest Holocene, the Black Sea was a freshwater lake [Degens and Ross, 1972]. As global sea level rose during the Holocene dense saline water from the Mediterranean flowed over the Bosporus sill, either as a torrent or more progressively, and sank below the fresh surface waters [Ryan et al., 1997; Lane-Serff et al., 1997; Arthur and Dean, 1998]. Very little mixing with the fresh water cap occurred, stratification ensued, and the bottom waters of the Black Sea became anoxic at $\sim 7.5 \mathrm{ka}$ [Jones and Gagnon, 1994; LaneSerff et al., 1997; Arthur and Dean, 1998]. The change from oxic to anoxic conditions at the sediment-water interface resulted in the preservation of a laminated, organic-rich sapropel (unit II [Calvert and Fontugne, 1987; Calvert, 1987; Hay et al., 1991; Arthur et al., 1994; Wilkin et al., 1997; Arthur and Dean, 1998]). The termination of unit II sapropel deposition occurred at $\sim 2 \mathrm{ka}$, following an increase in salinity to above $11 \%$ as saline bottom waters slowly mixed with the fresh surface waters. Increasing salinity allowed for the invasion of the coccolithophore Emiliania huxleyi, whose seasonal blooms initiated the deposition of the coccolith carbonate-rich laminated sediments of unit I [Hay et al., 1991; Arthur et al., 1994; Arthur and Dean, 1998]. Comprehensive reviews of the modern oceanography of the Black Sea are provided by Izdar and Murray [1991] and Degens and Ross [1974].

There has been much discussion over the past 20 years regarding the stratigraphy of the Holocene Black Sea sediments and, in particular, over the past 10 years regarding the sedimen-

Copyright 2001 by the American Geophysical Union

Paper number 1999PA000469

0883-8305/01/1999PA000469\$12.00 tological and geochemical relationship between the benthic flocculent or "fluff" layer and the underlying laminated sediments [Degens et al., 1978; Hay, 1988; Honjo et al., 1988; Hay et al., 1990; Pilskaln, 1991; Arthur et al., 1994; Jones and Gagnon, 1994; Arthur and Dean, 1998]. The debate has centered on the interpretation of the of the light/dark laminae as annual varves and the temporal and sedimentological relationship between a persistent or intermittent benthic fluff layer and the formation of the underlying sediment laminae. Varve chronologies, determinations of sediment accumulation rates from modern time series sediment trap samples, and detailed comparisons of varve and seasonal sediment trap sample components support the contention that the light/dark laminae couplets represent two-season annual varves [Arthur et al., 1994; Pilskaln, 1991; Hay, 1988; Hoy et al., 1990; Honjo et al., 1988]. The studies above have proposed that the thicker light laminae of unit I result from the summer-fall flux of coccolith-rich particulates produced by $E$. huxleyi blooms, mixing with lesser amounts of dinoflagellate material and resuspended fine shelf sediments. The thinner dark laminae are believed to be late winter-spring depositional products of diatoms and silicoflagellate blooms and seasonal peaks in riverine input of terrestrial lithogenics [Hay, 1988; Honjo et al., 1988; Hay et al., 1990, 1991]. In contrast to varve counting and sediment trap studies, radiocarbon dating and ${ }^{210} \mathrm{~Pb}$ mass accumulation rates suggest that the light/dark couplets may represent $>1$ year of deposition possibly due to the lack of complete couplets for years when annual coccolithophore blooms may not have occurred [Hay, 1988; Hay et al., 1991; Crusius and Anderson, 1992; Jones and Gagnon, 1994].

The successful recovery in 1988 of box cores containing the undisturbed benthic fluff layer, first documented photographically by Vine [1974], provided the opportunity for detailed studies of its age, geochemistry, and sedimentological role relative to the formation of the underlying light/dark laminae. Crusius and Anderson [1992] point out the necessity of determining the origin of the surficial fluff layer in the Black Sea as a means of addressing whether or not the laminae couplets do indeed repre- 
sent varves or not. They suggest three possible origins of the fluff: (1) it represents resuspended surficial sediment, (2) it is the product of an anomalous single depositional event, or (3) it is a permanent feature and results from steady state processes. The first option can be ruled out because of the geochemically distinct character of the fluff, as compared to the immediately underlying sediments, in terms of particulate organic carbon (POC), opal, carbonate and organic compound composition, and radionuclide inventories [Beier et al., 1991; Moore and O'Neill, 1991; Pilskaln, 1991]. The latter two scenarios for the fluff origin have significantly different implications regarding the accumulation of sedimentary laminae beneath the fluff, and thus a more concise understanding is required. In the present study, we combine geochemical and sedimentary data obtained from the fluff and the immediately underlying unit I sediments, along with detailed scanning electron microscope (SEM) and backscattered electron imagery (BSEI) analyses of unit I and II laminae from recently (1993) collected Black Sea gravity cores to characterize the relationship between the fluff and the light/dark sediment laminae.

\section{Methods}

\subsection{Box Cores and Surface Sediments}

Fifteen box cores ( $50 \times 50 \mathrm{~cm}$ surface area by $50 \mathrm{~cm}$ height) were collected in 1988 on Leg 1 of the R/V Knorr Black Sea Expedition, and four $6 \mathrm{~m}$ long gravity cores were obtained in 1993 on Leg 1 of the TREDMAR III cruise (Figure 1) [Honjo et al., 1988; Limonov et al., 1994]. The 1988 box cores used in the present study recovered all of unit 1 , including the benthic fluff layer in 13 cores [Honjo et al., 1988]. The 1993 gravity cores recovered the majority of unit I sediments (with the loss of only a top few centimeters) and the entire unit II sapropel (Figure 2). Detailed box coring and sampling procedures are given by Honjo et al. [1988] and Pilskaln [1991]. Approximately 100$200 \mathrm{~cm}^{3}$ of the surficial fluff layer $(\sim 2 \mathrm{~cm}$ thickness, where present) [Pilskaln, 1991] and $150-400 \mathrm{~cm}^{3}$ of the underlying $2 \mathrm{~cm}$ of sediment were subsampled from each box core and poisoned with $4 \%$ buffered formalin. The sediment samples were sieved through nylon sieves of $500,250,125$, and $63 \mu \mathrm{m}$ to size fractionate the sedimentary components; the fluff samples were not size fractionated by sieving as the material was all $<63 \mu \mathrm{m}$. Each sediment size fraction and fluff sample was examined and documented using light and scanning electron microscopy and then analyzed in triplicate for POC, calcium carbonate, opaline silica, and lithogenic content using standard wet-chemical procedures [Pilskaln, 1991]. A $1.0 \mathrm{M}$ acetic acid leach method was used to determine $\mathrm{CaCO}_{3}$ content based on dry sample weight loss. Decalcified samples were combusted at $500^{\circ} \mathrm{C}$ for 3 hours to quantify the total amount of combustible (organic) and noncombustible (biogenic opal plus lithogenic) content. POC was determined from decalcified samples with a CHN analyzer. Opaline silica content was analyzed by leaching decalcified samples with a $1.0 \mathrm{M} \mathrm{NaOH}$ solution and spectrometrically determining the amount of reactive silica in the leachate (modified from Eggimen et al., [1980]). Lithogenic content was calculated as the difference between total noncombustible and opal content (equal to biogenic $\mathrm{SiO}_{2}$ calculated from reactive silica.

\subsection{Gravity Cores and Sediment Fabric Analysis}

Detailed sedimentary logs of the four gravity cores recovered in 1993 were compiled from visual core description and smear slide analysis. Smear slides were made using toothpicksized sediment samples from four white and four dark laminae of unit I and four light and dark laminae samples from unit II (cores BS254 and BS256; Figure 2) and were mounted using Naphrax mounting media. Five $2 \mathrm{~cm} \times 2 \mathrm{~cm} x \sim 5 \mathrm{~cm}$ long intact sediment blocks were cut from cores BS250 and BS254 (Figure 2) and embedded using a fluid displacive, low-viscosity resin [Pike and Kemp, 1996]. Highly polished thin sections were produced from the resin-embedded sediment core blocks, carbon-coated, and analyzed with SEM BSEI following the procedure of Pike and Kemp [1996]. BSEI has become a widely employed method to analyze the sedimentary fabric of both modern and ancient laminated sediments [Krinsley et al., 1983; $P$ ye and Krinsley, 1984; Kemp, 1990; Macquaker and Gawthorpe, 1993; Pike and Kemp, 1996, 1997]. Sedimentary laminae that consist primarily of calcite/aragonite and terrigenous quartz and feldspar grains (comparatively large average atomic weights) have a high backscatter coefficient that produces relatively bright images. Laminations dominated by porous material (hence by low atomic weight, carbon-based resin filling the pore spaces), such as dinoflagellate thecae or cysts and siliceous diatom frustules, have a low backscatter coefficient and produce dark images. BSEI photomosaics of the thin sections were produced at $20 \mathrm{X}$ magnification and used as base maps for high magnification analyses of the sediment fabric and grain and laminae boundary relationships. SEM energy dispersive (EDS) elemental mapping of the thin sections provided laminae compositional information.

\subsection{Sediment Trap Samples}

Particulate material collected with a time series sediment trap that was deployed at $1200 \mathrm{~m}$ in the far western Black Sea [Honjo et al., 1988; Hay et al., 1990] was examined microscopically with SEM for the present study. The trap site, referred to as BSC, was located $80 \mathrm{~km}$ from the coast in $2100 \mathrm{~m}$ of water, with the $1200 \mathrm{~m}$ trap operating from June 1986-April 1988 [(Hay, 1988; Hay et al., 1990]. Splits of particulate samples collected in the spring of 1987 and 1988 (all prepoisoned with a $4 \%$ buffered formalin solution placed in the trap collection cups prior to deployment) were used in the present study.

\section{Results}

\subsection{BSC $1200 \mathrm{~m}$ Sediment Trap, Fluff Layer, and Underlying Surface Sediments}

Close inspection and careful sampling of the tops of the undisturbed 1988 box cores reveal a dark green-gray surface fluff layer of loose gelatin consistency (average thickness of $2 \mathrm{~cm}$ ) immediately underlain by a $2 \mathrm{~cm}$ thick gray-white sediment layer we call a protolaminae layer (Figure 3). The term "protolaminae" is used because the layer does not display the typical unit I white/dark laminae couplets or geochemical composition. Underneath these gray/white protolaminae are the distinctly laminated unit 1 sediments with the first clearly visible dark or black lamina dated at $\sim 70$ years prior to 1988 (Figure 3; Arthur 


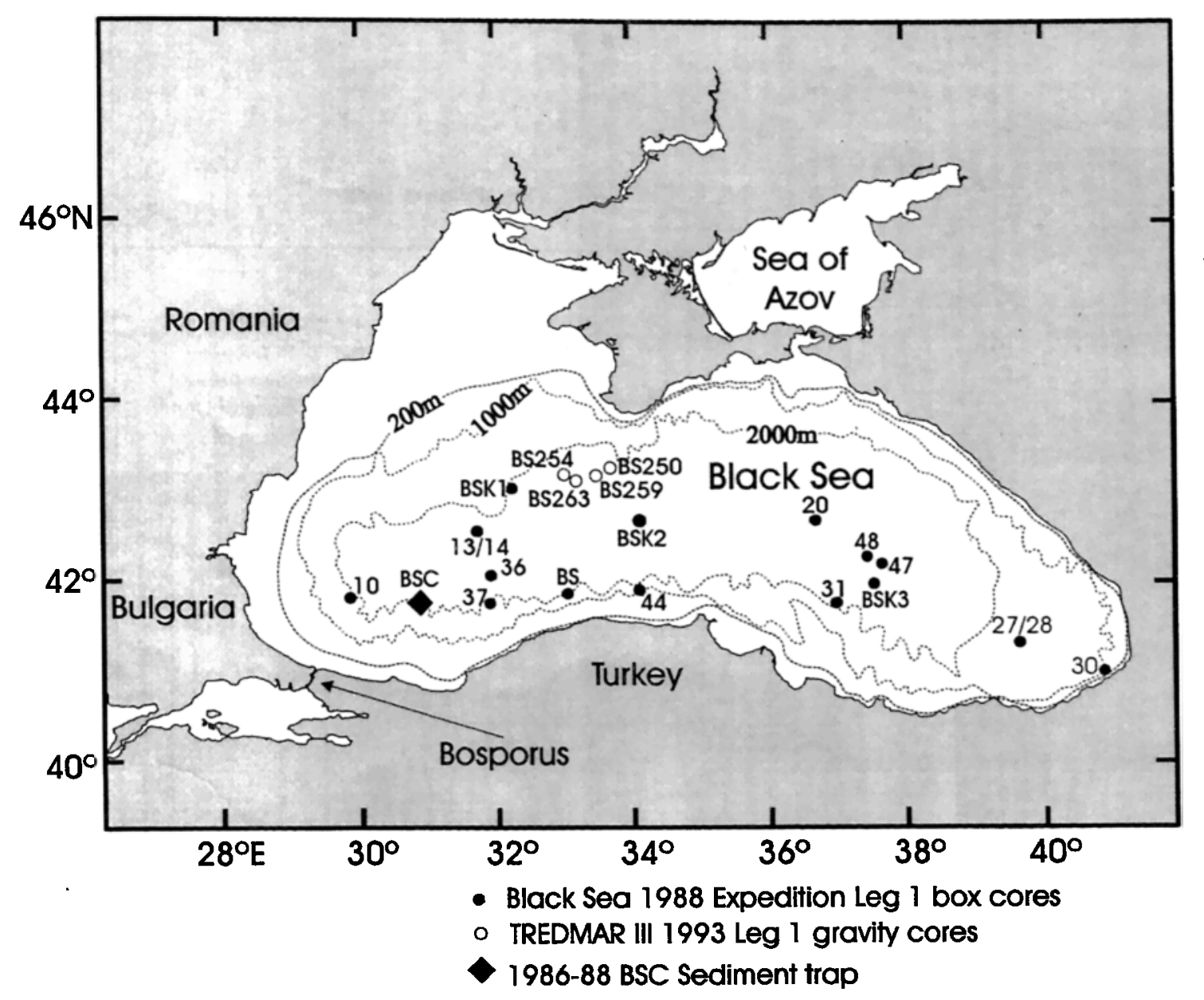

Figure 1. Location of Black Sea 1988 box cores, 1993 gravity cores, and 1986-1988 BSC time series sediment trap site.

et al, 1994). The size-fractionated, dry weight percent geochemical composition of the fluff layer and underlying surface sediments from the fifteen 1988 box cores is presented in Table 1. Mean geochemical compositional values for all the sediment size fractions and overlying fluff layers were reported previously by Pilskaln [1991]; here we report the sedimentary geochemical data for each station to demonstrate the minimal variability occurring among the 1988 sites located throughout the Black Sea basin, along with new SEM and/or BSEI photomicrographic studies completed on the sediments, fluff layers, and BSC trap material. Coccolithophore E. huxleyi-dominated zooplankton fecal pellets and coccolith-rich aggregates with moderate amounts of diatom skeletal material were collected in the 1200 $\mathrm{m} \mathrm{BSC}$ traps in summer 1987 (Figure $4 \mathrm{a}$ ). In comparison, the contents of pellets and aggregates from the $1200 \mathrm{~m}$ BSC trap material collected in the spring 1988 show an abundance of diatom tests (primarily Rhizosolenia sp.) and silicoflagellate skeletons with no coccoliths (Figures $4 b-4 d$ ). The sediment fluff layer samples collected during the spring of 1988 have a mean composition (over 12 sites) of $31 \% \mathrm{CaCO} 3,6 \%$ opal, $7 \%$ POC and $47 \%$ lithogenic represented by clay minerals (Table 1 ). The opal content is provided by the presence of highly etched diatoms and silicoflagellate skeletal elements with minor to moder- ate amounts of surface etching; $\mathrm{CaCO}_{3}$ content is provided by an abundance of $E$. huxleyi coccoliths (Figures 5a-5d). Fecal pellets concentrated just below the fluff layer and within the graywhite proto-laminae sediments (Figures $6 \mathrm{a}$ and $6 \mathrm{~b}$ ) have a very high coccolith carbonate content (always $>50 \%$ by dry weight), occasional preservation of the periotrophic membrane, and minor to moderate amounts of intact diatom and silicoflagellate tests (Figures $6 \mathrm{c}-6 \mathrm{f}$ ). The fluff layer and the underlying $2 \mathrm{~cm}$ of sediments are both dominated by $\mathrm{CaCO}_{3}$ and lithogenic material, with calcium carbonate being somewhat enriched in the sediments compared to the fluff layer (Table 1). There is a slight decrease in the percent opal content between the fluff layer and the underlying sediments (without a comparable increase in the relative percentage of lithogenic material), whereas percent $P O C$ remains relatively constant (Table 1).

\subsection{Units I and II: BSEI Analyses and Laminated Sediment Fabric}

The four abyssal plain gravity cores were correlated with the Holocene stratigraphy from Hay et al. [1990] and the accelerator mass spectrometry (AMS) radiocarbon ages provided by Jones and Gagnon [1994] (Figure 2). Visual examination of the split- 


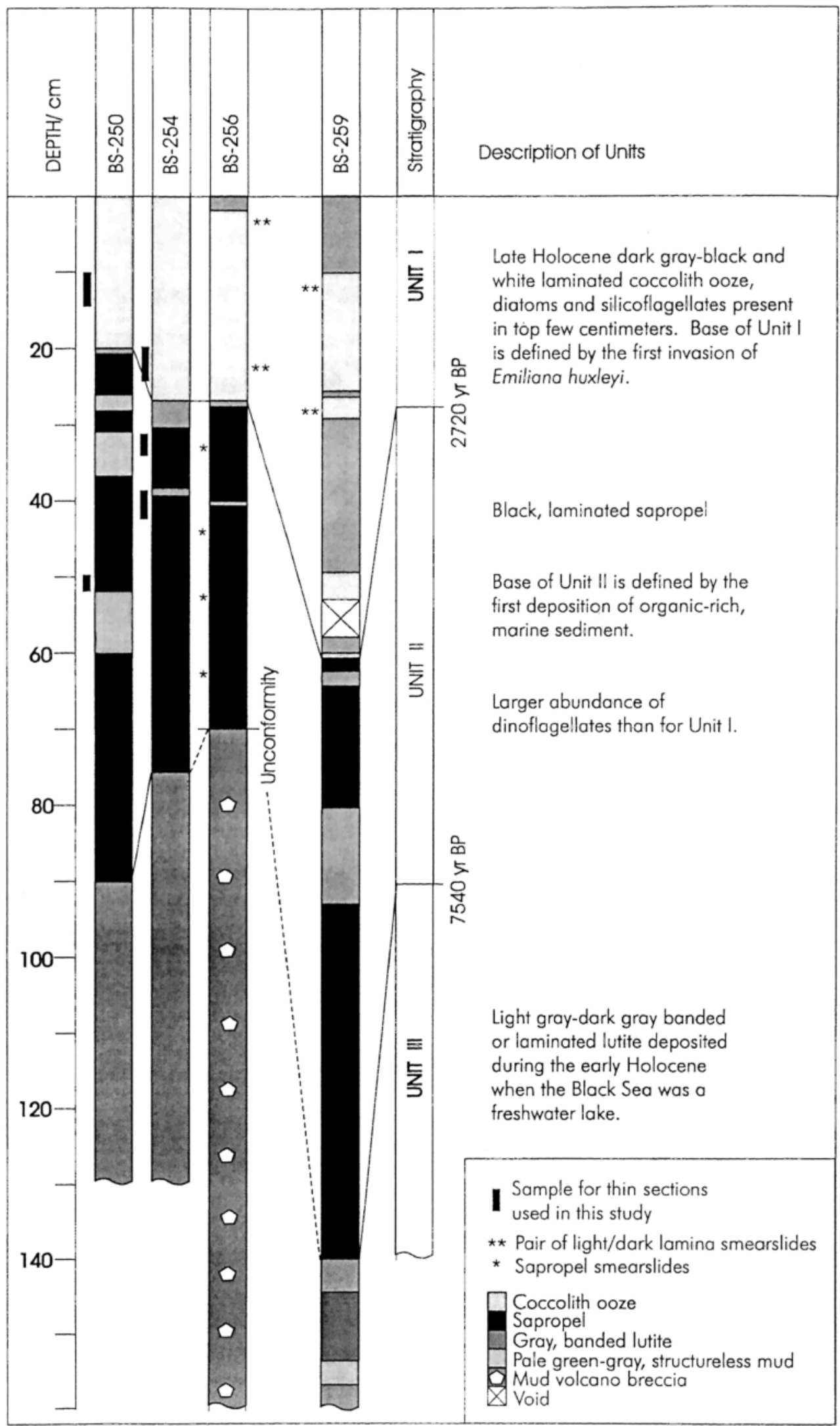

Figure 2. Holocene stratiographic correlation of four 1993 Black Sea gravity cores with that of Hay et al. [1990] and with Jones and Gagnon [1994] radiocarbon ages. 

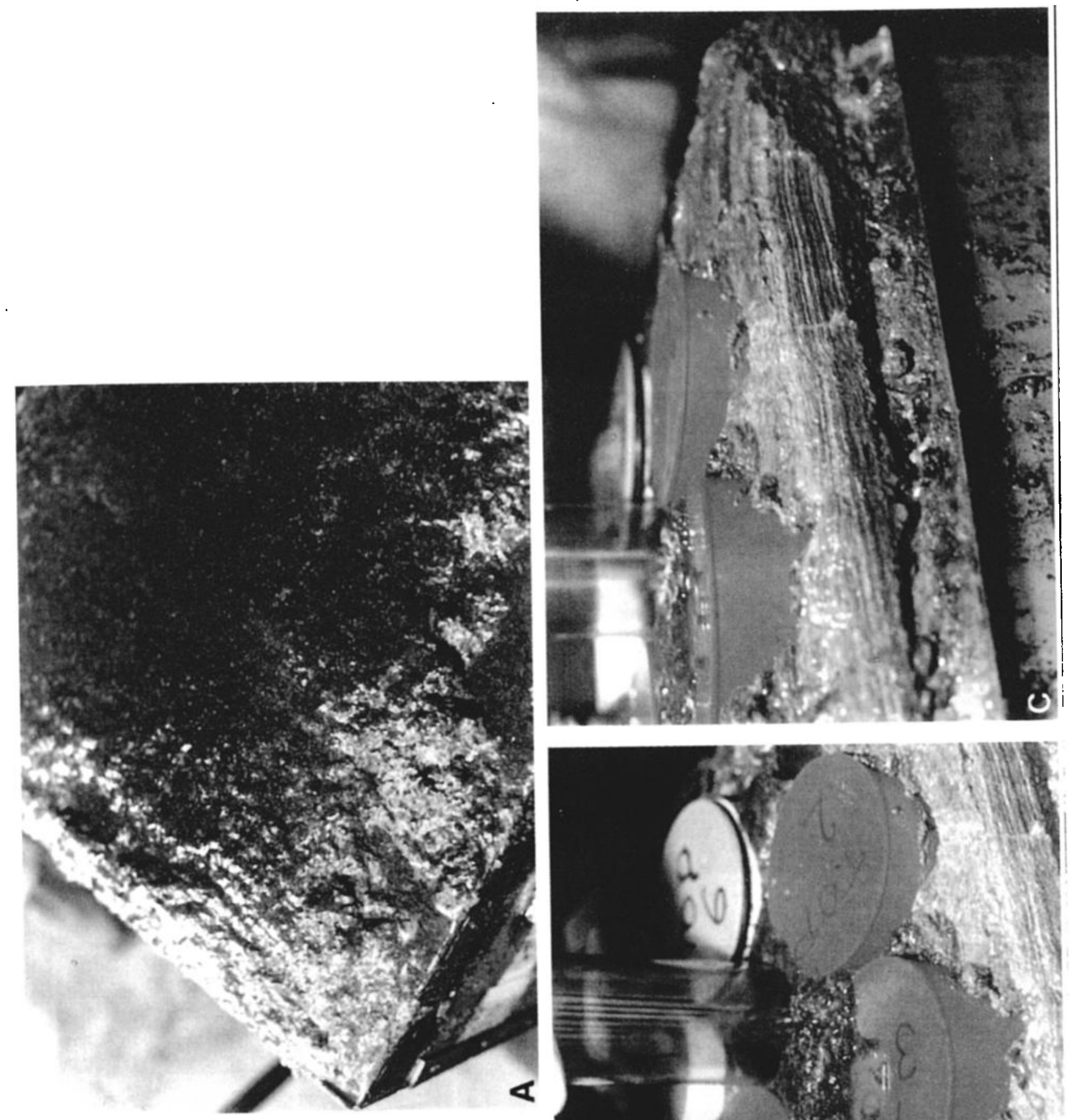

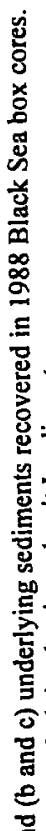

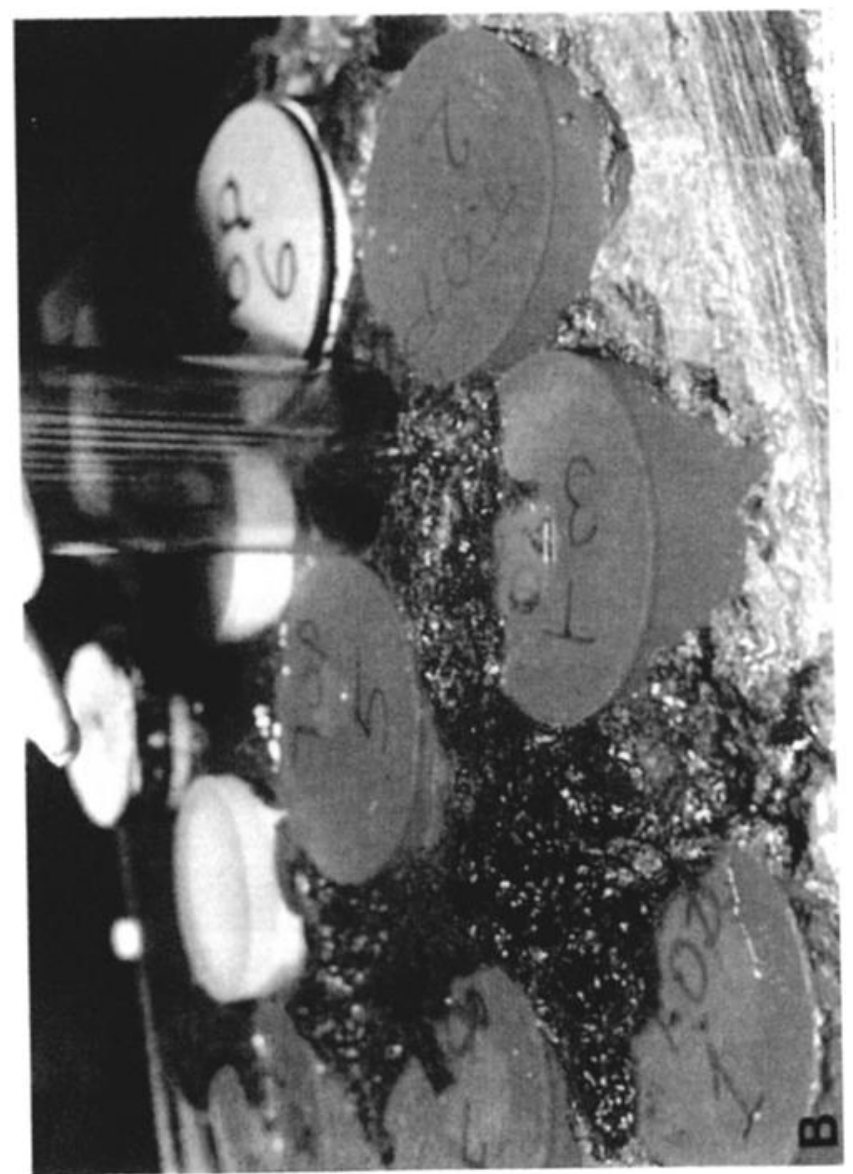

호를

离

总

8

穹 응

瓷

올

空

政

至

产

可先

는

항

응 즌

온 홍

的最

証

然要 
Table 1. Geochemical Composition of Black Sea Fluff Layer and Underlying $2 \mathrm{~cm}$ of Seived Sediments

\begin{tabular}{|c|c|c|c|c|c|}
\hline Map site & Sediment Size Fraction & Percent $\mathrm{CaCO}_{3}$ & Percent Opal & Percent POC & Percent Lithogenic \\
\hline 10 & fluff & 29 & 11 & 6 & 33 \\
\hline 10 & $>500 \mathrm{~mm}$ & 66 & 3 & 4 & 23 \\
\hline 10 & $500-250 \mathrm{~mm}$ & 57 & 3 & 8 & 26 \\
\hline 10 & $250-125 \mathrm{~mm}$ & 43 & 4 & 10 & 28 \\
\hline 10 & $125-63 \mathrm{~mm}$ & 37 & 4 & 9 & 39 \\
\hline 10 & $<63 \mathrm{~mm}$ & 37 & 2 & 4 & 51 \\
\hline $13 / 14$ & fluff & 55 & 2 & 6 & 29 \\
\hline $13 / 14$ & $>500 \mathrm{~mm}$ & 58 & 4 & 6 & 23 \\
\hline $13 / 14$ & $500-250 \mathrm{~mm}$ & 57 & 3 & 5 & 26 \\
\hline $13 / 14$ & $250-125 \mathrm{~mm}$ & 45 & 4 & 9 & 31 \\
\hline $13 / 14$ & $125-63 \mathrm{~mm}$ & 36 & 6 & 10 & 36 \\
\hline $13 / 14$ & $<63 \mathrm{~mm}$ & 41 & 4 & 7 & 36 \\
\hline BSKI & $>500 \mathrm{~mm}$ & 64 & 4 & 5 & 23 \\
\hline BSK1 & $500-250 \mathrm{~mm}$ & 56 & 4 & 7 & 25 \\
\hline BSK1 & $250-125 \mathrm{~mm}$ & 36 & 4 & 8 & 36 \\
\hline BSKl & $125-63 \mathrm{~mm}$ & 46 & 4 & 10 & 30 \\
\hline BSKl & $<63 \mathrm{~mm}$ & 40 & 6 & 7 & 38 \\
\hline BSK2 & fluff & 29 & 4 & 6 & 51 \\
\hline BSK2 & $>500 \mathrm{~mm}$ & 60 & 4 & 5 & 23 \\
\hline BSK2 & $500-250 \mathrm{~mm}$ & 53 & 4 & 7 & 26 \\
\hline BSK2 & $250-125 \mathrm{~mm}$ & 43 & 4 & 8 & 36 \\
\hline BSK2 & $125-63 \mathrm{~mm}$ & 37 & 4 & 8 & 41 \\
\hline BSK2 & $<63 \mathrm{~mm}$ & 29 & 4 & 9 & 54 \\
\hline 20 & $>500 \mathrm{~mm}$ & 68 & 3 & 4 & 21 \\
\hline 20 & $500-250 \mathrm{~mm}$ & 56 & 4 & 7 & 27 \\
\hline 20 & $250-125 \mathrm{~mm}$ & 47 & 3 & 8 & 31 \\
\hline 20 & $125-63 \mathrm{~mm}$ & 36 & 4 & 12 & 34 \\
\hline 20 & $<63 \mathrm{~mm}$ & 41 & 3 & 6 & 42 \\
\hline BSK3 & $>500 \mathrm{~mm}$ & 48 & 3 & 6 & 41 \\
\hline BSK3 & $500-250 \mathrm{~mm}$ & 54 & 4 & 10 & 23 \\
\hline BSK3 & $250-125 \mathrm{~mm}$ & 44 & 6 & 12 & 24 \\
\hline BSK3 & $125-63 \mathrm{~mm}$ & 26 & 5 & 15 & 38 \\
\hline BSK 3 & $<63 \mathrm{~mm}$ & 29 & 5 & 3 & 53 \\
\hline 48 & fluff & 51 & 4 & 6 & 31 \\
\hline 48 & $>500 \mathrm{~mm}$ & 70 & 3 & 4 & 19 \\
\hline 48 & $500-250 \mathrm{~mm}$ & 62 & 4 & 5 & 23 \\
\hline 48 & $250-125 \mathrm{~mm}$ & 41 & 6 & 9 & 31 \\
\hline 48 & $125-63 \mathrm{~mm}$ & 33 & 6 & 15 & 25 \\
\hline 48 & $<63 \mathrm{~mm}$ & 54 & 3 & 5 & 32 \\
\hline 47 & fluff & 33 & 9 & 7 & 29 \\
\hline 47 & $>500 \mathrm{~mm}$ & 67 & 4 & 4 & 21 \\
\hline 47 & $500.250 \mathrm{~mm}$ & 58 & 2 & 6 & 26 \\
\hline 47 & $250-125 \mathrm{~mm}$ & 42 & 9 & 11 & 27 \\
\hline 47 & $125-63 \mathrm{~mm}$ & 34 & 6 & 13 & 32 \\
\hline 47 & $<63 \mathrm{~mm}$ & 51 & 3 & 5 & 34 \\
\hline $27 / 28$ & fluff & 30 & 7 & 8 & 45 \\
\hline $27 / 28$ & $>500 \mathrm{~mm}$ & 47 & no data & 4 & no data \\
\hline $27 / 28$ & $500-250 \mathrm{~mm}$ & 48 & 4 & 7 & 34 \\
\hline $27 / 28$ & $250-125 \mathrm{~mm}$ & 34 & 6 & 9 & 38 \\
\hline $27 / 28$ & $125-63 \mathrm{~mm}$ & 26 & 6 & 9 & 47 \\
\hline $27 / 28$ & $<63 \mathrm{~mm}$ & 29 & 6 & 4 & 54 \\
\hline 36 & fluff & 29 & 6 & 4 & 54 \\
\hline 37 & fluff & 28 & 6 & 7 & 49 \\
\hline BS & fluff & 24 & 7 & 6 & 56 \\
\hline 44 & fluff & 16 & 7 & 8 & 69 \\
\hline 31 & fluff & 32 & 6 & 6 & 47 \\
\hline 30 & fluff & 11 & 8 & 9 & 72 \\
\hline
\end{tabular}


Table 1. (continued)

\begin{tabular}{llcccc}
\hline Map site & Sediment Size Fraction & Percent $\mathrm{CaCO}_{3}$ & Percent Opal & Percent POC & Percent Lithogenic \\
\hline All site mean & fluff & 31 & 6 & 7 & 47 \\
All site mean & $>500 \mathrm{~mm}$ & 61 & 4 & 5 & 24 \\
All site mean & $500-250 \mathrm{~mm}$ & 56 & 4 & 7 & 26 \\
All site mean & $250-125 \mathrm{~mm}$ & 42 & 5 & 5 & 31 \\
All site mean & $125-63 \mathrm{~mm}$ & 35 & 5 & 11 & 36 \\
All site mean & $<63 \mathrm{~mm}$ & 39 & 4 & 6 & 44 \\
All site mean & all size fractions (excluding fluff) & 46 & 4 & 8 & 32. \\
\hline
\end{tabular}
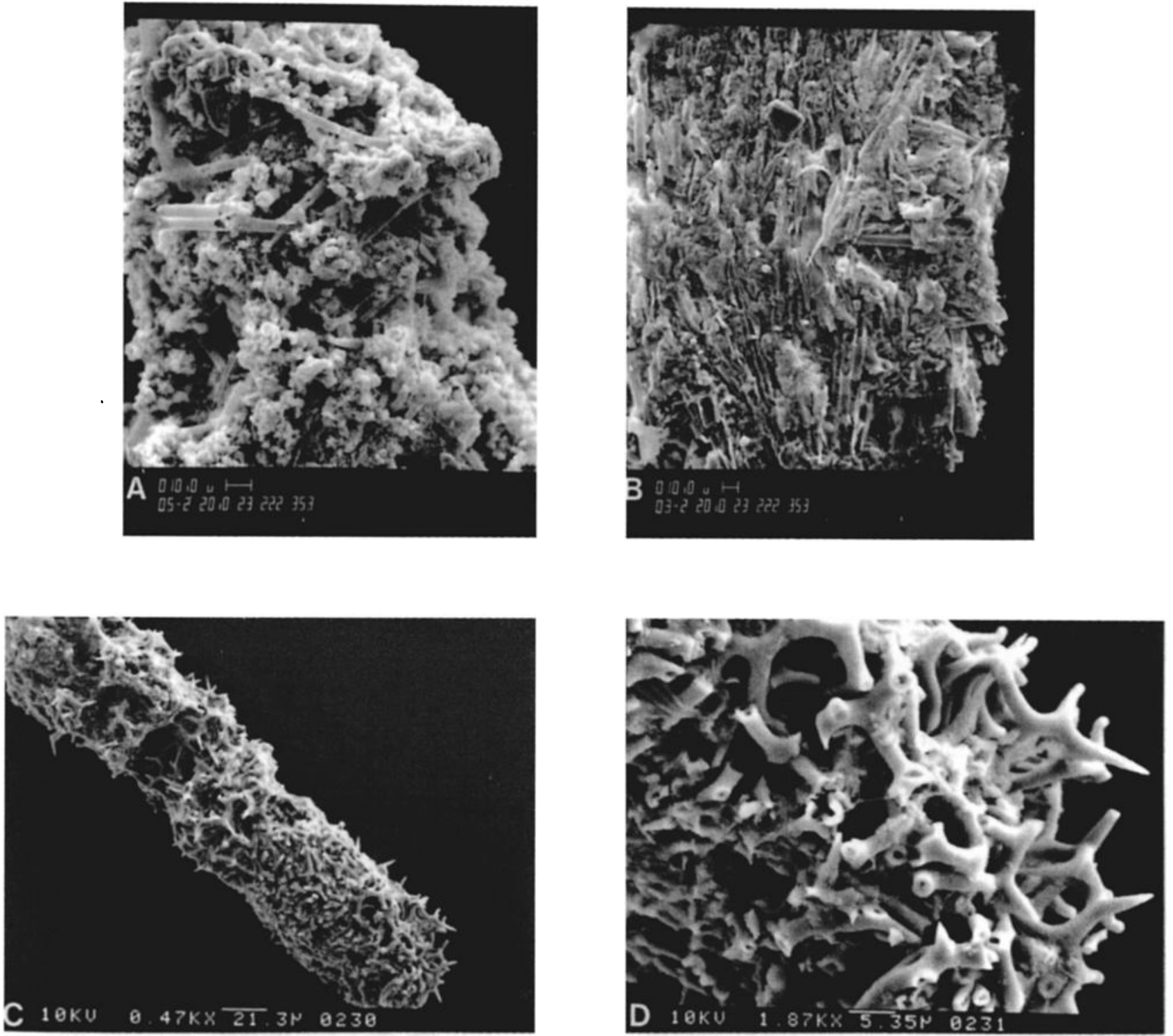

Figure 4. Scanning electron microscope (SEM) micrographs of fecal pellets and fecal aggregates collected in the $1200 \mathrm{~m}$ BSC sediment trap, summer 1987 and spring 1988. (a) Summer 1987 fecal aggregate consisting primarily of coccolithophore $E$ huxleyi and lesser amount of diatom frustules. (b) Spring 1988 fecal pellet packed with Rhizosolenia frustules. (c and d) Zooplankton fecal pellet from spring 1988 packed with silicoflagellate Distephanus skeletal material. Scale bars in microns are at bottom of each micrograph. 

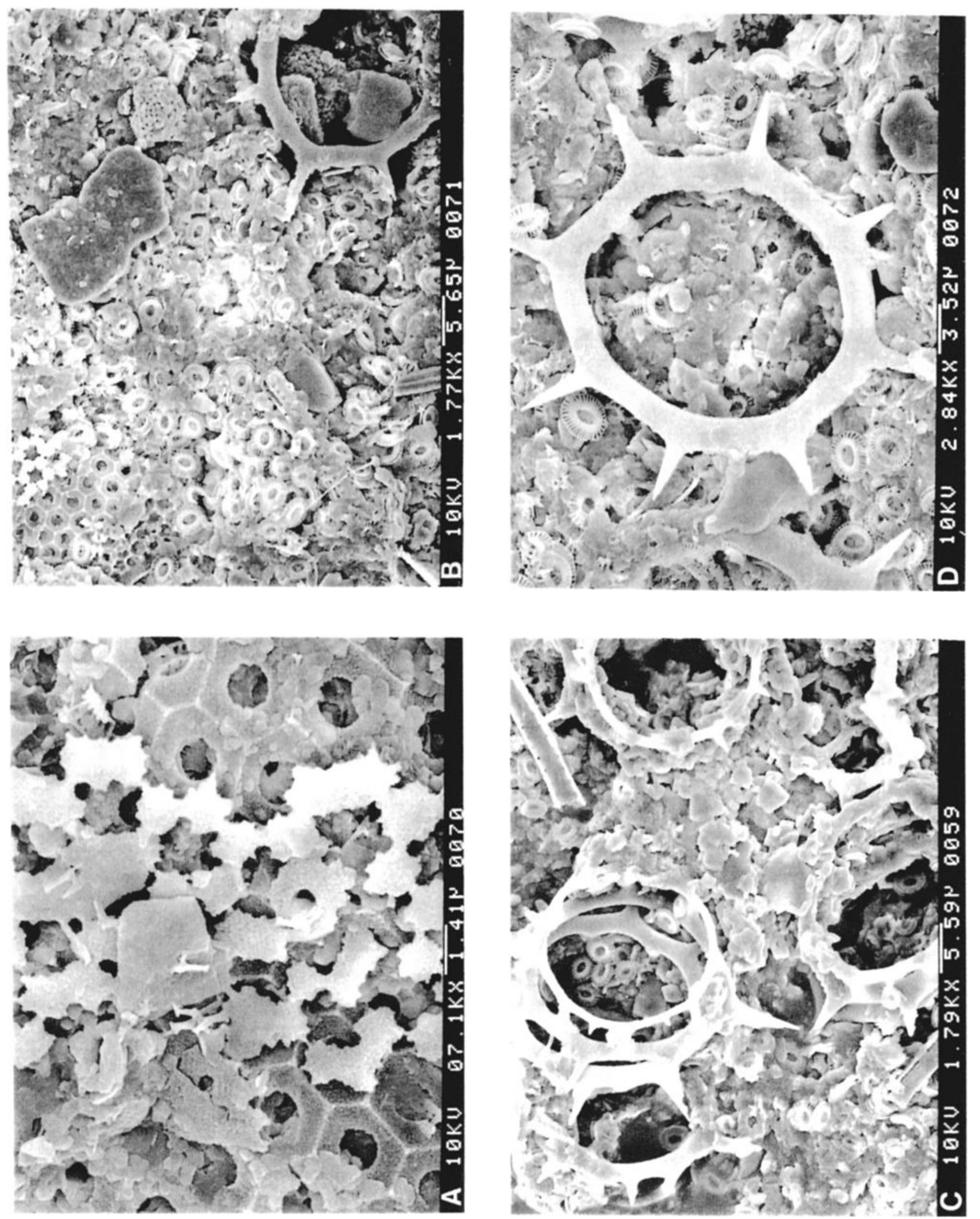

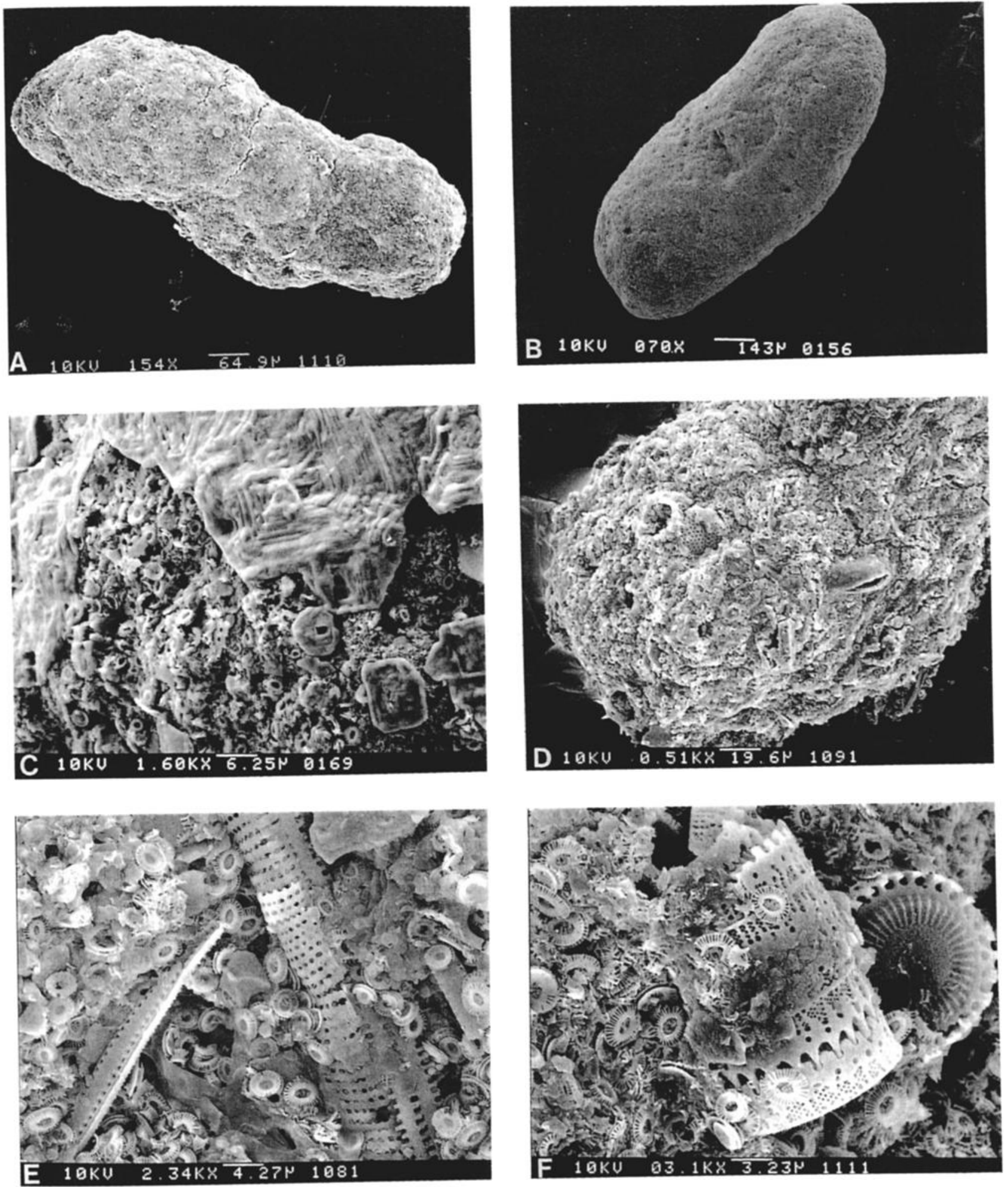

Figure 6. SEM micrographs of ( $a$ and $b$ ) fecal pellets concentrated below the fluff layer within the gray-white protolaminae, (c) preserved penotrophic membrane on fecal pellet which acts to protect opaline silica constituents from dissolution, and (d-f) pellets containing large amounts of coccolith carbonate and minor amounts of datom and silicoflagellate opal. All scale bars are in microns. 
core surfaces and smear slides made from Unit I sediments collected by the 1993 gravity cores shows consistent submillimeterto millimeter-scale alternation between white laminae, rich in $E$. hixleyi coccoliths, and dark gray to black laminae containing silt, clays, and organic debris, as expected from the results of previous Black Sea core laminae analyses [Hay, 1988; Hay, and Honjo, 1989; Hay et al., 1991; Arthur et al., 1994]. BSEI analyses combined with SEM elemental mapping show that the compositional alternation in unit I sediments consists of three lamina types: (1) a white, $\mathrm{CaCO} 3$-rich lamina displaying comparatively high backscatter coefficients; (2) lamina composed mainly of lithogenic material, having an intermediate backscatter coefficient and appearing dark gray in color; and (3) black organicrich lamina consisting of amorphous organic matter, occasional diatom and silicoflagellate skeletal elements, dinoflagellate cysts, and coccoliths with a very low backscatter coefficient (Figures 7 and 8). Lamina types 2 and 3 combine to produce the dark gray to black laminations seen in visual core analysis and represent the dark or black lamina of the varve couplets described by Hay [1988] and Hay et al. [1990, 1991]. The thicker, white (bright under BSEI) laminae are coccolith-rich, composed primarily of coalesced, pellet-shaped aggregates of coccoliths with pinched ends and minor amounts of lithogenic material (Figures $8 \mathrm{a}, 8 \mathrm{~b}, 8 \mathrm{c}$, and $8 \mathrm{e}$ ). Occasional occurrences of coccolith-rich, white laminae in which the coccolith aggregates (200$500 \mu \mathrm{m}$ in length) are not entirely coalesced laterally are also seen in the BSEI images of the cores (Figure 8b). The coccolith-rich laminae tend to have sharp boundaries and a distinct bulbous/pinch-and-swell-type character (Figures 8a, 8b, and 8e). Many of the thickest coccolith-rich laminae are laterally continuous across the $2 \mathrm{~cm}$ wide sediment blocks cut from the gravity cores (Figure 7). In the dark gray lithogenic-rich laminae displaying intermediate backscatter coefficient, loose coccoliths are observed along with pellet-shaped lithogenic aggregates, 500-600 $\mu \mathrm{m}$ in length (Figure 8f). The lithogenic aggregates occasionally coalesce to produce an appearance similar to the coalesced coccolith aggregates (compare Figures $8 \mathrm{e}$ and $8 \mathrm{f}$ ). The black, low backscatter coefficient laminae consist primarily of amorphous organic matter, diatom skeletal remains, and dinoflagellate cysts (Figures $8 \mathrm{~b}, 8 \mathrm{~d}, 8 \mathrm{~g}$, and $8 \mathrm{~h}$ ) and appear to be sandwiched or compressed in between the thicker, coccolith-rich and lithogenic-rich laminae, giving them a thin, wavy character (Figures $8 \mathrm{~b}$ and $8 \mathrm{~d}$ ). On close inspection, these thin, dark laminae display a more porous character than either of the other two types of laminations (Figures 8e-h). Coccolith aggregates are rare or absent from the dark, organic-rich laminae, although occasional loose coccoliths are observed (Figures $8 \mathrm{a}, 8 \mathrm{~b}, 8 \mathrm{~d}$, and $8 \mathrm{~g}$ ). Subsamples from the dark, organic-rich laminae in the upper part of unit I (Figure 2) are found to contain more skeletal opal remains than similar laminae at the base of unit $\mathbf{I}$.

Unit Il sediments (Figure 2; deposited between $\sim 2-7.5 \mathrm{ka}$, [Jones and Gagnon, 1994] consist of laminated, gray to black, fine silt/clay sediments with a complete absence of $E$. huxleyi as determined by visual and smear slide analysis. BSEI analyses reveal two distinct laminae types in unit $\mathrm{II}$, in contrast with the three of unit I (Figure 9, Figures 10a and 10b). Light- colored, intermediate backscatter coefficient laminae are composed of coalesced and noncoalesced, thick lens-shaped lithogenic aggregates of up to several 100 microns in length (Figures :0a-10c).

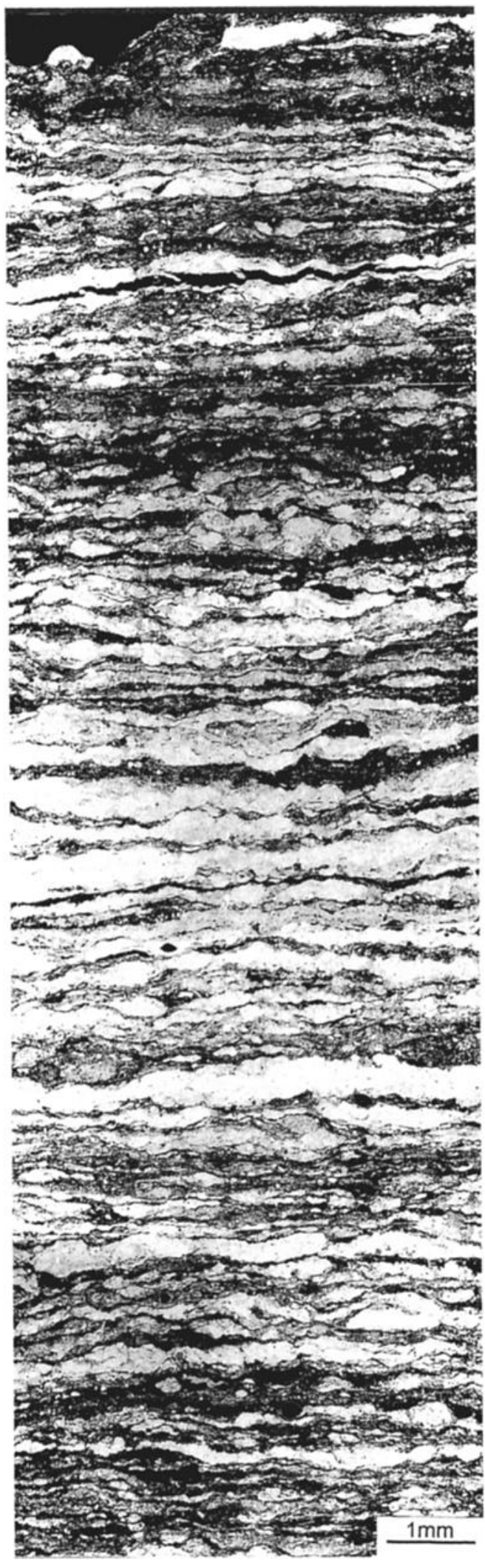

Figure 7. BSEI photomosaic of Holocene unit I coccolith ooze from 1993 gravity core (BS254, 23-25 cm). 
These laminae have a pinch-and-swell appearance similar to the white, coccolith-rich laminae of unit I (Figures 8b, 8d, 10a, and 10b). Dark, low backscatter coefficient laminae consist of amorphous organic matter, isolated lithogenic grains, dinoflagellates, and extremely rare, poorly preserved diatom frustules (Figures $10 \mathrm{a}, 10 \mathrm{~d}$, and $10 \mathrm{e}$ ). The dark laminae of unit II have a thin, wavy character and appear more porous as compared to the thicker, light-colored lithogenic laminae (Figures 10a-d). Overall, the individual laminae of unit II tend to be thinner than those of unit I (Figures 7 and 9).

\section{Discussion}

\subsection{Opal in the Benthic Fluff Layer and theFormation of Unit I Dark Laminae}

Geochemical and microscopic analyses of the fluff layer collected in spring 1988 , as compared to the underlying protolaminae sediments, suggest that a significant portion of the components within the fluff layer represent the sedimentation products of the winter-spring period when diatom and silicoflagellate blooms occur and terrigenous and lithogenic material input to the water column is enhanced owing to high river runoff and storm-generated shelf resuspension [Hay et al., 1990]. Numerous silicoflagellate skeletons and highly etched diatom valves are present in the 1988 fluff layer, in addition to a high abundance of single coccoliths and clay mineral particles. A significant source of the latter two particle types is the winter storm resuspension and lateral offshore advection of shelf sediments containing detrital clastic material and coccolith debris [Hay and Honjo, 1989; Hay et al., 1990]. In contrast to the spring $1200 \mathrm{~m}$ BSC trap samples in which silicoflagellate and diatom-packed pellets are observed, no such pellets composed exclusively of silicoflagellate or diatoms are seen in the fluff. However, fecal pellets (some possessing a semi-intact periotrophic membrane) composed primarily of coccoliths and containing well-preserved diatom and silicoflagellate tests were collected from the sediments underlying the fluff layer in 1988 . Considering the mean opaline silica content of the spring 1988 trap material (50\%) and the fluff layer opal content of $6 \%$, we assume that the majority of opaline skeletal material which reaches the deep waters of the Black Sea dissolves at the sediment-water interface within the fluff layer. Evidence supporting high opal loss rates at the interface comes from the documentation of diatom-poor sediments in the Black Sea despite relatively high fluxes measured in the water column and the occurrence of extremely etched surfaces of opal skeletal components within the surface sediments immediately underlying the surface fluff layer [Shimkus and Trimonis, 1974; Hay et al., 1990; Hay et al., 1991; Pilskaln, 1991]. It appears that even though the upper Black Sea water column $(250 \mathrm{~m})$ is highly undersaturated with respect to silica [Brewer, 1971; Hay et al., 1990] as compared to deeper waters (1200 m), opaline skeletal material that becomes incorporated into fastsettling fecal pellets (and into sinking algal aggregates) may escape dissolution in the upper water column, sink to the deep water column, and upon disintegration, release silicoflagellates and diatoms to the basin floor and fluff layer. Some degree of dissolution protection of the opal within sinking pellets may be provided by periotrophic membranes, thereby increasing the probability of successful incorporation of the opal into the sedi- ments. Thus the very small amount of biogenic opal preserved in the Black Sea sediments underlying the fluff layer ( $4 \%$ opal in the $2 \mathrm{~cm}$ of sediment immediately underneath the fluff and $<1 \%$ opal over the remainder of unit I) is likely derived from pellet-bound opaline material produced by suspension feeding zooplankton in the overlying water column throughout the year.

The mass flux of particulate material through the Black Sea water column in the winter-spring consists primarily of biogenic opal, lithogenic particles (clay minerals), and terrigenous debris and is quantitatively less than thai occurring during summer-fall periods of maximum $\mathrm{POC}$ and $\mathrm{CaCO}_{3}$ fluxes [Hay, 1988; Hay et al., 1990]. Although no seasonal fecal peilet counts have been completed on Black Sea trap samples, microscopic examination of the BSC trap samples reveals a greater abundance of intact fecal pellets in the summer-fall samples than in the winterspring samples. Pellet production might be lower in winterspring, leading to a reduced delivery of fecal pellets to the sediment-water interface during this time of the year as compared to the summer-fall. Considering this as well as the high dissolution loss of opal relative to calcium carbonate in the Black Sea [Shimkus et al., 1973; Shimkus and Trimonis, 1974; Pilskaln, 1991; Hay, 1988; Hay and Honjo, 1989; Hay et al., 1990], one would expect the winter-spring depositional laminae to be substantially thinner overall than those resulting from the coccolith

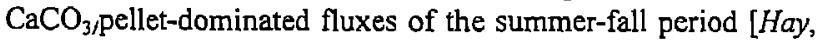
1988; Hay and Honjo, 1988]. The BSEI analyses of Black Sea gravity cores support this expectation with thinner, dark, more lithogenic and opal-rich dark laminae observed interlayered between the thicker, bulbous white coccolith laminae of unit I. Our detailed BSEI study indicates that winter-spring sedimentation events actually produce two distinguishable lamina: a dark gray, lithogenic-rich lamina and a black, organic-rich/opal lamina, which together form the single dark or black lamina of the Black Sea varve couplets easily recognized in core sections. Hay et al. [1990] suggest that diatom blooms occurring in the winter-spring might effectively remove more suspended terrigenous/lithogenic material from the water column by physical scavenging compared to the summer-fall coccolithophore blooms owing to the winter-spring peak in river discharge into the Black Sea. Our data indicate that the flux of terrigenous/lithogenic material may not be primarily associated with the flux and delivery of diatom opal as we observe distinctly lithogenic-rich laminae as well as more organic-rich/diatom opal-containing laminae. However, the lack of diatom opal resulting from dissolution in the lithogenic-rich laminae must also be considered. The occurrence of pellet-shaped, lithogenic aggregates in our type 2, dark gray, lithogenic-rich laminae may represent winter-spring deposited zooplankton fecal pellets in which the opal has dissolved.

\subsection{Role of Fecal Pellets in the Formation of Unit I White Laminae}

Results from the above described analyses indicate that the thick, white laminae in unit 1 result from the deposition of densely packed, coccolith-rich zooplankton fecal pellets and coccolith-packed marine snow aggregates which settle out of the water column during the summer-fall season when $E$. hwoleyi blooms are prevalent in the Black Sea [Hay, 1988; Pilskaln, 1991; Diercks and Asper, 1997]. The well-preserved fecal pel- 

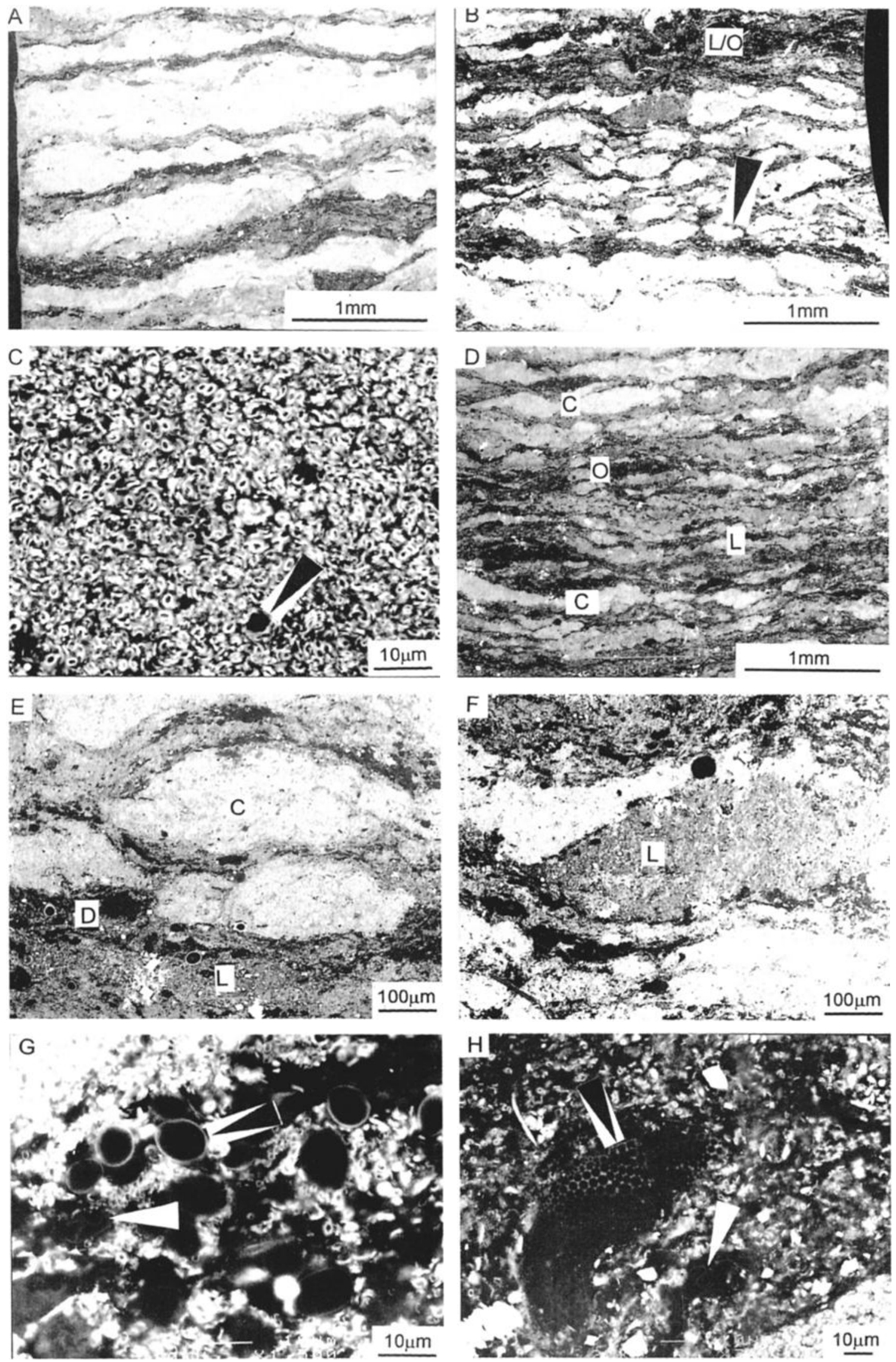
lets recovered in 1988 and concentrated below the fluff are coccolith-rich and represent the most abundant sedimentary components within the two largest sieve fractions $(\geq 250 \mu \mathrm{m})$ of the surface sediments [Pilskaln, 1991]. The pellets and pellet fragments appear to be incorporated into the pellet-rich and $\mathrm{CaCO}_{3}$ rich $\left(>90 \% \mathrm{CaCO}_{3}\right)$ white laminae of unit I [Hay, 1988]. This lamina type displays a high BSEI backscatter signal consistent with a dense, coccolith carbonate content. Microscopic examination of the white laminae fabric reveals a structure highly suggestive of an accumulation of fecal pellets that resemble in size and composition those planktonic zooplankton pellets collected in sediments immediately underlying the 1988 fluff layer (compare Figures 6a, 6b, and 8e). Because E. huxleyi produces massive blooms in the summer-fall period as reflected in the composition of Black Sea sediment trap samples, we concur with Hay [1988] and Hay et al. [1990; 1991] that the white laminae in unit I sediments are a summer-fall depositional product, with the primary mechanisms of transport to the sedimentwater interface being zooplankton fecal pellets with a lesser contribution by coccolith-rich marine snow aggregates. The varying thickness of the white laminae and the pinch-and-swell character is a reflection of the interannual variations in the total mass flux of coccolith-rich pellets and/or marine snow. This is supported by evidence from modern Black Sea sediment trap showing that the magnitude of the E. huxleyi blooms varies between years and occasionally blooms may not occur [Hay, 1988; Hay and Honjo, 1988; Hay et al., 1990].

Although the summer-fall white laminae are full of coccoliths, they are poor in organic carbon relative to the black, organic-rich/opal laminae. This is somewhat puzzling considering the fact that sediment traps have measured the highest annual POC fluxes through the water column during the summer-fall period of coccolithophorid blooms [Hay, 1988; Hay et al., 1990]. Organic biomarker studies of Black Sea surface sediments are somewhat ambiguous in terms of the relative importance of coccolithophores, diatoms, and terrestrial higher plants in contributing to sedimentary organic carbon [Wakeham and Beier, 1991]. One possible explanation for the lack of POC in the white laminae may be that the POC produced and exported to the sediment-water interface in the form of pellets and aggregates following coccolithophorid blooms is highly labile, rapidly oxidized, and results in a relatively organic-poor but calcite-rich white lamina. The amorphous organic matter within our Black Sea type 3 thin black laminae and within the largely terrigenous black laminae described by Hay [1988] may be of higher plant origin and possibly of a more refractory nature.

\subsection{Hydraulic Sorting and Geochemical Transformations Within the Fluff Layer}

Owing to its gelatinous nature, we suggest that the benthic fluff layer acts as a hydraulic sorting layer through which dense, heavy particles or aggregates (such as coccolith-packed zooplankton fecal pellets) will sink quickly but small, less dense particles (such as individual coccoliths and platy clay minerals or spinose silicoflagellates and porous diatom valves), will not. In this manner, the fluff layer plays an important role in determining how rapidly planktonically derived particulates become incorporated into the underlying sediments and the extent of preaccumulation remineralization of opal and POC. A factor to consider in examining the potential hydraulic particle-sorting occurring in the fluff layer is the accumulation of bacterial populations within the layer and the potential physical/chemical effects which their presence may have on particle sorting. A secondary maximum in sulfate reduction in the Black Sea occurs below the water column oxic-anoxic interface in the underlying surface sediments and has been attributed to a high abundance of fermentive bacteria as well as methanogens, with the latter found to be concentrated in the benthic fluff layer [Jannasch et al., 1974; Jannasch, 1991; Muramoto et al., 1991]. Karl [1978] reports adenine triphosphate (ATP) concentrations within the top $10 \mathrm{~cm}$ of Black Sea sediments that are 4 orders of magnitude higher than that of the overlying water column, a direct indication of the elevated level of bacterial metabolic activity in the uppermost sediments. Additionally, Jannasch et al. [1974] report the presence of atypical anaerobic, sulfide-oxidizing bacteria in the surface sediments. Unlike the more typical sulfideoxidizing thiobacilli that are absent from the Black Sea surface sediments and tend to lower the $\mathrm{pH}$ of culture media by forming sulfate, the atypical isolates actually raise or have little effect on the $\mathrm{pH}$ of the medium [Jannasch et al., 1974]. Analyses of the organic biomarker composition of Black Sea surface sediments and benthic fluff layer tend to corroborate the findings of the above microbial studies. Beier et al. [1991] and Wakehom and Beier [1991] suggest the presence of a patchy microbial community concentrated within the upper $1 \mathrm{~mm}$ of the benthic fluff layer based on sterol and fatty acid analyses of the fluff layer. High concentrations of bacteria either on the surface or within the fluff layer may impede or slow the movement of platy, spinose and/or porous particles through the layer, thus reducing their potential burial rate and possibly enhancing the degradation of the more labile organic-rich particles and/or the dissolution of opal material. Results of the Jannasch et al. [1974] study suggests that the presence of particular bacteria might produce a slight increase in the $\mathrm{pH}$ of the fluff or surface sediments, which would facilitate opal dissolution.

We propose that the fluff layer represents a geochemical transition layer within which all sinking particulate material is hydraulically sorted and opal and POC components are remineralized. The mean 1986-1988 opaline silica content of trapcollected particulates from the $1200 \mathrm{~m} \mathrm{BSC}$ trap is 20 and $50 \%$ for summer-fall and winter-spring samples, respectively. This compares to an opal content of $6 \%$ determined for the 1988

Figure 8. BSEI micrographs of sections from unit I mosaic (Figure 7) showing (a) bright pinch-and-swell-type $\mathrm{CaCO}_{3}$-rich laminae; (b) laminae of noncoalesced pellet-shaped aggregates of coccoliths (indicated by arrow), with a thicker lamina composed of lithogenic material and organic debris at the top (labeled $\mathrm{L} / \mathrm{O}$ ); (c) coccoliths within a $\mathrm{CaCO}_{3}$-rich aggregate, with intact coccolithophore sphere indicated by arrow; (d) thin, wavy lamination composed of lithogenic material (L), discontinuous organic-rich lamina $(\mathrm{O})$, and pinch-and-swell-type $\mathrm{CaCO}_{3}$-rich laminae (C); (e) coalesced $\mathrm{CaCO}_{3}$-rich coccolith aggregates (C) above organic-rich lamina composed of dinoflageilate cysts (D) and lithogenic-rich lamina (L); (f) large (600 $\mu \mathrm{m})$ lithogenic/silt aggregate $(L)$, with intermediate backscatter signal; $(g$ and $h$ ) remains of diatoms (black arrows) and dinoflagellate cysts (white arrows) in the more porous, dark, low backscatter laminae. 


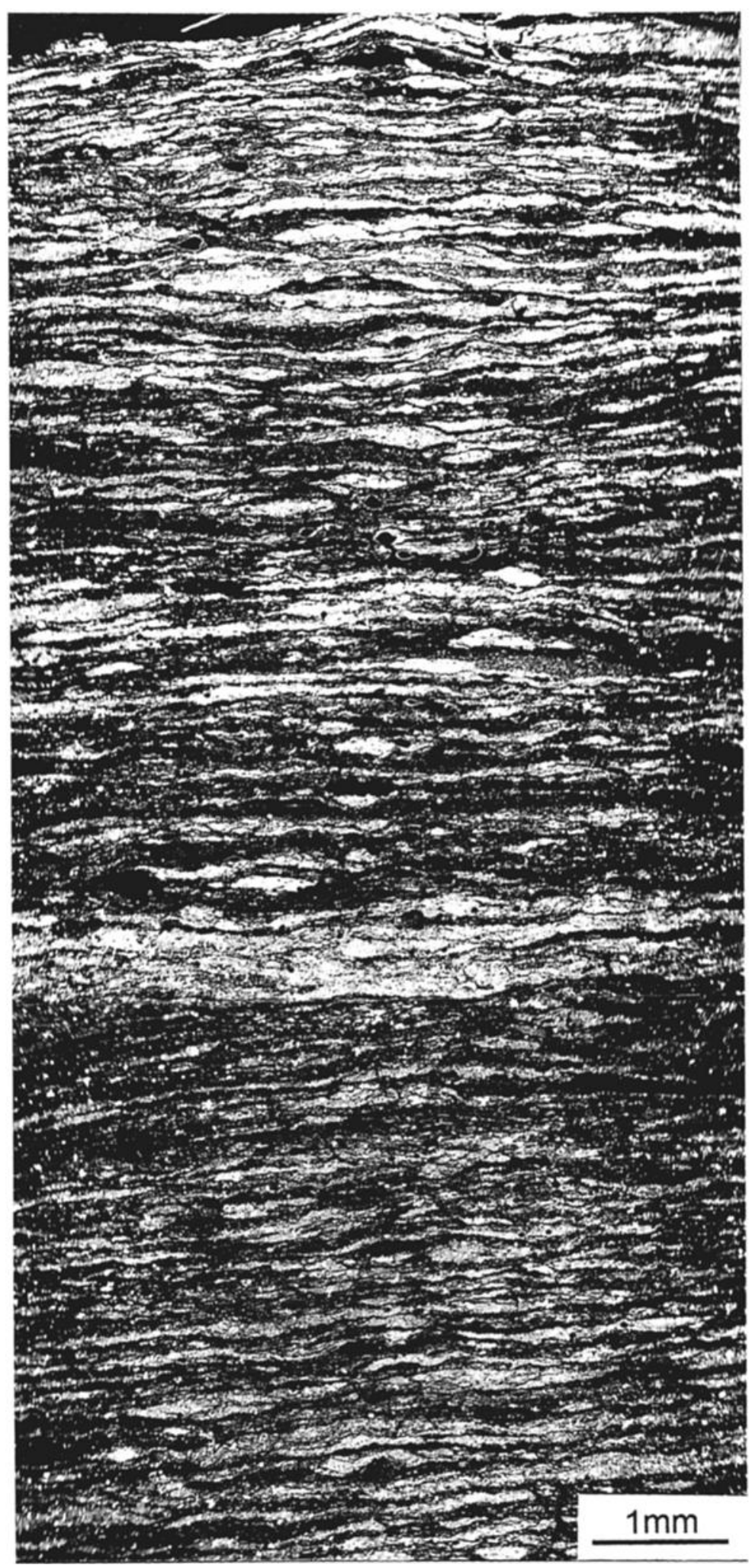

Figure 9. BSEI photomosaic of unit II sapropel from 1993 gravity core (BS250, $50-51.2 \mathrm{~cm}$ ) 

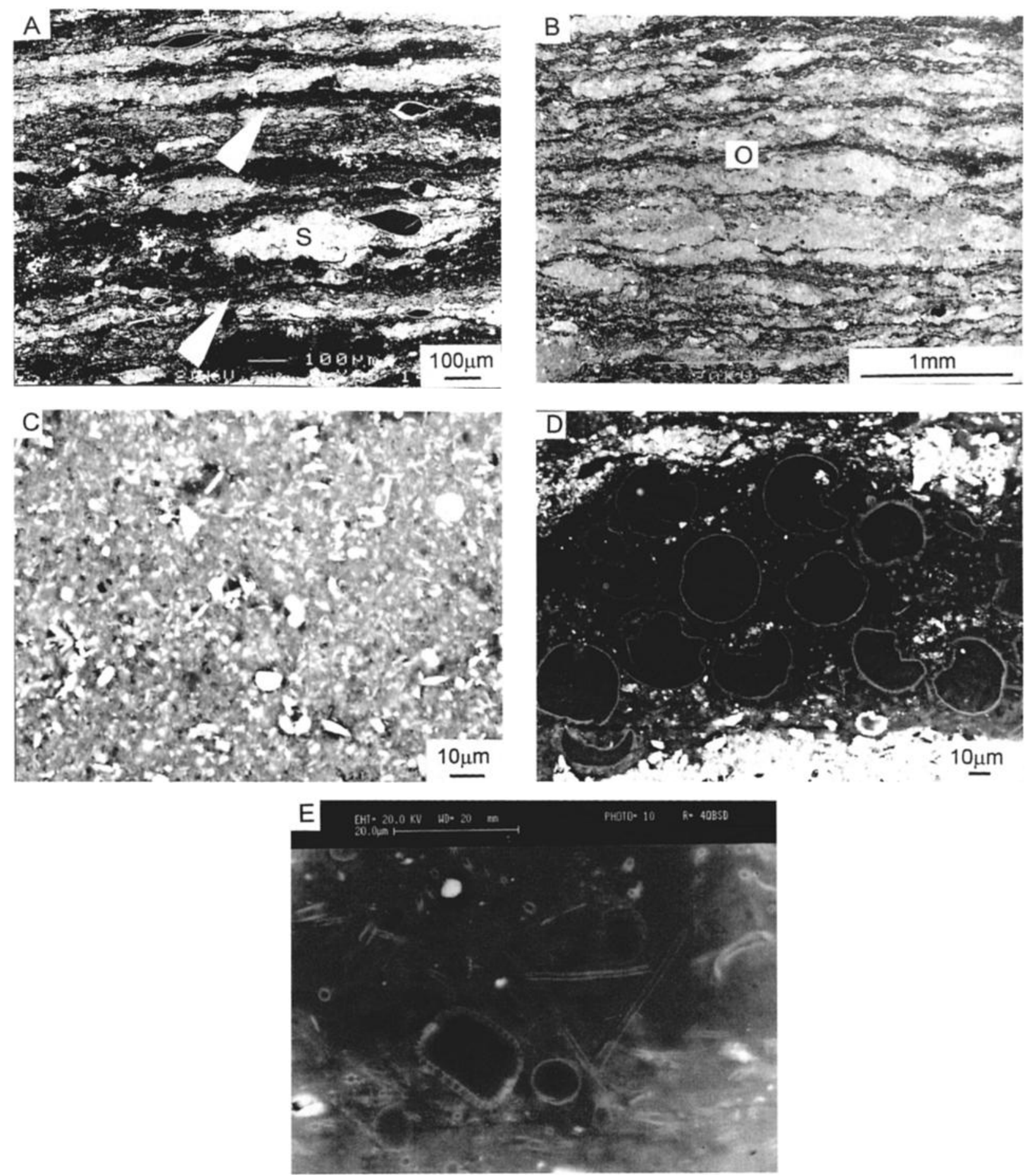

Figure 10. BSEI micrographs of sections from unit II mosaic (Figure 9) showing (a) thin, dark, wavy organic-rich laminations (indicated by arrows) and noncoalesced, brighter lithogenic aggregates (S); (b) coalesced lithogenic-rich aggregates forming bulbous, pinch-and-swell-type laminae alternating with thin, dark, organic-rich laminae (O); (c) silt- and clay-sized particles in a lithogenic aggregate; (d) dinoflagellate cysts within a dark, organic-rich lamina, (e) last vestiges of diatom frustules within a dark, organic-rich lamina (micrograph is overbrightened to show the very poorly preserved opaline frustules).

collected fluff within which highly etched diatom valve fragments are found. If minimal dissolution of the settling opal material occurs between $1200 \mathrm{~m}$ and the bottom $(2000 \mathrm{~m})$ with the majority occurring at the sediment-water interface, as suggested by Hay et al. [1990], then we observe a 70-80\% dissolu- tion loss of biogenic silica within the fluff layer. Spinose silicoflagellates and porous diatom valves settling slowly through the gelatinous fluff layer are particularly vulnerable to dissolution with their characteristically high surface area:volume ratios. Further postdepositional dissolution of opal must occur as it is 
compacted and incorporated into the laminae of unit I (supported by pore fluid data from Manheim and Chan [1974]), which has a mean opal content of $<1 \%$ [Shimkus and Trimonis, 1974; Hay, 1988]. Dissolution loss of coccolith $\mathrm{CaCO}_{3}$ appears to be minimal to negligible throughout the deep waters, fluff layer, and surface sediments of the Black Sea. The high calcium carbonate content of the summer-fall settling particulate material, fluff. and underlying sediments is preserved in unit I (and enhanced by additional POC and opal degradation loss), which has a mean $\mathrm{CaCO}_{3}$ content of $65 \%$ [Hay, 1988; Hay et al., 1991).

The fluff layer microbial community most likely facilitates remineralization of POC delivered to the benthic fluff layer. POC fluxes to the sediment-water interface are highest during the summer-fall, representing $15 \%$ of the total flux (by dry weight) at BSC compared to a mean of $8 \%$ POC content for the winter-spring trap material [Hay, 1988; Hay and Honjo, 1989; Hay et al., 1990]. If we compare these values to the $7-8 \%$ POC content of both the 1988 fluff layer and the underlying protolaminae sediments, a maximum loss of $50 \%$ of the seasonally delivered $P O C$ is observed. Considering the finding that the majority of sinking POC recycling occurs in the shallow $60-80$ $\mathrm{m}$ ) suboxic waters of the Black Sea, with relatively low rates of decomposition in the permanently anoxic zone [Karl and Knauer, 1991], high remineralization rates of POC at the sediment-water interface and within the surface sediments are necessary to explain the difference between the POC content of the deep trapped particulates, benthic fluff, and underlying surface sediments.

\subsection{Temporal Relationships Between the Fluff Layer, Seasonal Particulate Fluxes, and Laminae Formation}

A widespread, permanent benthic fluff layer probably developed soon after the establishment of anoxic basin conditions and the exclusion of a benthic macrofaunal community [Deuser, 1974; Ross and Degens, 1974; Calvert, 1987]. Extremely slow mixing of the bottom waters, with a near-bottom convective layer of an age that is of the order of the mean residence time of the basin, indicates that physical flow does not play a role in the disturbance and/or dispersal of the benthic fluff layer [Ozsoy et al., 1991]. Physical disturbance of the fluff layer should be expected during the emplacement of homogeneous, fine-grained layers of what have been termed turbidites in Black Sea cores [Ross and Degens, 1974; Hay et al., 1991; Lyons, 1991; Arthur et al., 1994). However, the deposition of these layers (several centimeters to tens of centimeters thick) appears to occur with little or no erosion as evidenced by the lack of any disruption of laminae couplet chronology [Arthur et al., 1994]. Thus the fluff layer must be left relatively undisturbed and/or become reestablished immediately following the low-energy emplacement of these layers. Support for this scenario comes from the observation that many of the box cores obtained in 1988 sampled thick, well-developed fluff layers immediately overlying a finegrained, gray "turbidite" layer of several centimeters thickness [Honjo et al., 1988; Lyons, 1991].

The fluff layer collected in 1988 consists of springproduced, biogenic opal particles and a notable high abundance of single coccoliths and clay particles. Both coccoliths and clays are extremely small particles, only micron-scale in size, and thus would be expected to display substantially reduced to negligible individual settling velocities through the gelatinous fluff layer. Because these components are not subject to the geochemical transformation processes of dissolution or degradation that affect the opal and organic carbon particle elements in the fluff layer, they may remain suspended in the layer for long periods of time. On the basis of our hypothesis that the benthic fluff layer is a permanent particle sorting and geochemical transition layer, we expect the composition of the layer at any one point in time to reflect the sorting and geochemical processes operating on the seasonally delivered particle components. Thus the benthic fluff will likely have a high content of individual coccolith and clay minerals and an absence of dense, heavy aggregates (such as fecal pellets and marine snow aggregates), regardless of the season, owing to hydraulic sorting as well as the conditions that favor chemical preservation of calcium carbonate in the Black Sea basin [Shimkus and Trimonis, 1974; Hay, 1988]. The amount of opaline silica and POC within the fluff layer will vary intra-annually as the delivery rate or flux of these materials fluctuates seasonally and as they are subject to dissolution and degradation processes upon reaching the sediment-water interface. In this manner, the fluff layer's composition is geochemically transitional on a seasonal basis dependent upon the seasonal delivery of particulate flux constituents (i.e., relatively higher opal following spring blooms, higher coccolith carbonate following summer-fall periods, etc.), but it is a physically permanent feature of the Black Sea sediment-water interface. Heavy or dense aggregated particulate material will tend to settle through the fluff and accumulate at the base, although fecal pellets full of opaline diatom and silicoflagellate material and without a periotrophic membrane may disintegrate quickly at the sediment-water interface. The amount of opal accumulating at the base of the fluff layer will largely be a function of whether or not it is protected within fecal pellets.

On the basis of our study and the dating of the uppermost laminated sediment of unit I recovered in the 1988 box cores [Arthur et al., 1994] we are able to place the surface sediments and fluff layer into a temporal framework relative to the seasonal particulate flux and the underlying laminated sediments of unit I. In Figure 11 we present a model of Holocene laminae formation using the data presented in this paper, along with previously published Black Sea sediment trap flux and gravity core data. A distinctive black lamina located at approximately the base of our $2 \mathrm{~cm}$ protolaminae layer, which we sampled beneath the fluff layer, has been dated at 70 years prior to 1988 [Arthur et al., 1994]. Thus we propose that this $2 \mathrm{~cm}$ protolaminae layer represents $\sim 70$ years of deposition prior to our sampling of it in 1988, with an estimated sedimentation rate of 28 $\mathrm{cm} \mathrm{kyr}^{-1}$. This rate compares reasonably well with the sedimentation rates reported by Hay [1998] and Arthur et al. [1994] ranging from 20 to $27 \mathrm{~cm} \mathrm{kyr}^{-1}$. Thus the heavy, aggregated, and/or pellet-protected seasonal particle flux components will settle through the fluff layer and accumulate at the base, forming the protolaminae. Early diagenetic processes of POC oxidation and opal dissolution will alter the geochemical and microfossil contents of these protolaminae as they accumulate and are buried. Pellets or aggregates settling through the fluff layer may shed small coccoliths, clay minerals, spinose silicoflagellates, and diatoms. These small particles could also be delivered individually to the benthic fluff layer via 


\section{Black Sea Particulate Sedimentation and Laminae Formation}

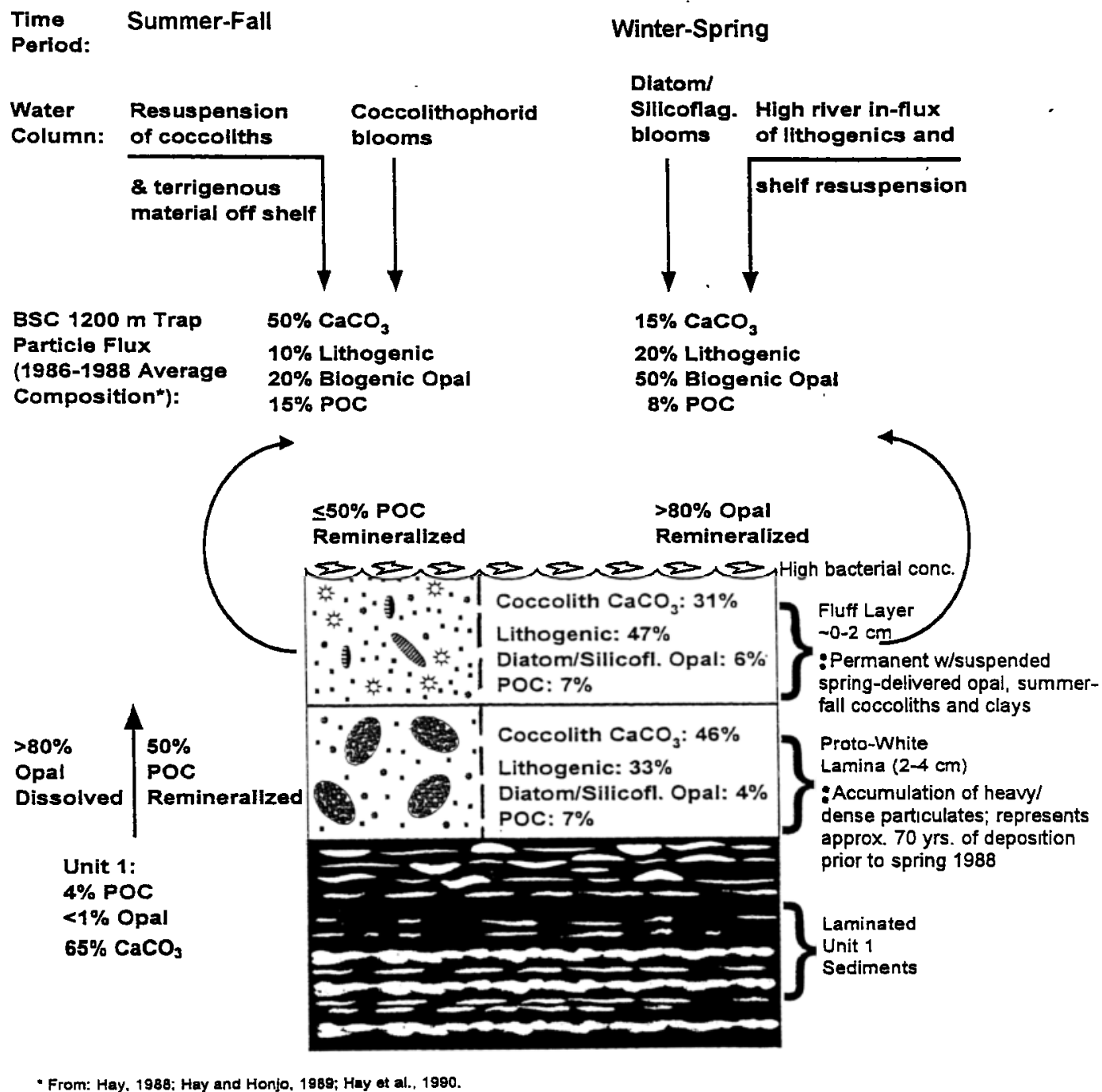

Figure 11. Schematic model of particulate sedimentation and Holocene laminae formation in the abyssal Black Sea based on modern sediment trap data and analyses of surface sediments and gravity cores.

winter resuspension and lateral offshore advection of shelfdeposited coccoliths and clays, disintegration of pellets or marine snow aggregates within the deep water and a shedding of opaline and calcareous components, or via individual sinking of frustules through the water column. Those particles not subject to rapid dissolution or degradation will remain in the fluff layer as semipermanent components. Individual coccoliths and platy clay minerals appear to be the most abundant semipermanent components of the fluff layer as well as consistent components of the protolaminae above the unit I laminated sediments.

The ideal sedimentological consequence of the above processes is the formation of a thick, light and thin, dark laminae couplet or varve per year. In reality, interannual variability in the magnitude of phytoplankton blooms and river runoff leads to the documented variations in the relative thickness of individual lamina from year to year. Additionally, it is possible that very large magnitude but short duration flux events such as algal blooms might result in the rapid deposition of dense aggregates and fecal pellets that could physically disrupt the previous season's protolaminae at the base of the fluff. This might produce the observed discontinuous horizontal structure of some individual lamina and a partial disruption of the laminae chronology. The possibility that complete couplets may not be deposited every year because of the occasional lack of a coccolithophore bloom makes light/dark laminae counts problematic and further complicates the formation of the ideal laminated sediment record in the Black Sea.

\subsection{Laminae Formation in Black Sea Unit II}

We propose for the unit II sapropel a similar scenario of laminae couplet formation and role of the fluff layer as for unit I. BSEI analyses of units I and Il laminae reveal that although 
they are different in macroscopic appearance and composition (unit II has no coccolith- $\mathrm{CaCO}_{3}$ and unit II bright laminae are thinner than the white, coccolith-rich laminae of unit I), the overall microscopic sediment fabrics of the two units are similar. Both are typified by thick, laterally continuous light-colored laminae with a pinch-and-swell character and a backscatter signal that makes them appear light colored or white. In between these bright laminae are the dark, thinner, more discontinuous laminae with a wavy character and a weak BSEI backscatter signal. The light-colored laminae of unit II have a coalesced and noncoalesced pellet-shape character similar to the thick white laminae of unit $I$, suggesting that they are also composed of primarily zooplankton fecal pellets and fecal aggregates.

The seasonal representation of the unit II laminae may be different than that hypothesized for the laminae of unit I. We speculate that the highest seasonal POC fluxes occurring during the time of unit II deposition were concentrated during spring diatom bloom periods (especially between 5 and $3 \mathrm{ka}$, when elevated organic carbon accumulation rates in unit II have been attributed to high levels of primary productivity) [Hay, 1988; Hay et al., 1990]. Siliceous diatom and silicoflagellate material was packaged into rapidly settling, POC-rich zooplankton fecal pellets and algal aggregates in the spring, the latter of which may have scavenged large amounts of suspended terrigenous/lithogenic material from the water column, assuming river input and storm resuspension of shelf sediments was high during the winter-spring period. The light, bulbous laminae of unit II represent the depositional product of these fecal pellets and algal aggregates. However, dissolution loss of the majority of the pellet and aggregate-bound opal material coupled with microbial degradation of an unknown amount of the organic matter delivered in the pellets and algal aggregates has produced the largely terrigenous/lithogenic composition of these unit II laminae [Hay et al., 1990]. In contrast, the thinner, dark laminae of unit II probably resulted from summer-fall particle export when production was dominated by dinoflagellates (which tend to sink individually and rarely are incorporated into fecal pel- lets) and POM export levels were relatively smaller [Sorokin, 1983]. If the scenario above is correct, the summer-fall laminae might contain some diatom fragments but would consist largely of dinoflagellate and amorphous organic debris as our BSEI analyses have shown. Therefore, as suggested by Hay et al. [1990], the light and dark laminae of unit II, like unit I, represent the depositional products of contrasting seasons and associated plankton blooms, with postdepositional dissolution of opal and organic carbon remineralization producing a predominantly terrigenous and lithogenic laminae composition.

\section{Conclusions}

Results of this study provide a hypothesized model of the temporal and geochemical relationships between the seasonal particle flux, the benthic fluff layer, and underlying Holocene unit I sediments. Chemical transformations and particle hydraulic sorting occurring in the permanent benthic fluff layer are important processes that are key to understanding underlying laminae formation. The new data presented here confirm but also refine the basic interpretations presented by previous workers of the paleoflux events responsible for the seasonal varve formation in the Black Sea. High-resolution BSEI examination of unit I laminae and geochemical and microscopic examination of the top $4 \mathrm{~cm}$ of sedimentary material in the Black Sea indicates that seasonal paleofluxes of zooplankton fecal pellets appear to be the primary mechanism by which seasonal deposition occurs and siliceous microfossils are preserved.

Acknowledgements. C.H.P, thanks the captain and crew of the R/V Knorr for the successful 1988 Black Sea Expedition, acknowledges NSF grant OCE-8614557 for funding, and thanks E. Degens (postmortem), S. Honjo, B. Hay, S. Manganini, J. Broda, J. Muromoto, and V. Asper for assistance at sea/in the lab and for helpful and insightful discussions. J.P. gratefully acknowledges NERC for her participation on the 1993 TREDMAR III R/V Gelendzhik Black Sea cruise and thanks Kate Davies at Southampton Oceanography Centre for drafting assistance. C.H.P. dedicates this paper to the memory of F. D'Escrivan-Hay, a great source of support, laughter, and friendship for many members of the 1988 Black Sea Expedition.

\section{References}

Arthur, M. A., and W. E. Dean, Organic-matter production and preservation and evolution of anoxia in the Holocene Black Sea Paleoceanography, 13, 395-411, 1998.

Arthur, M. A., W. E. Dean, E. D., Neff, B. J. Hay, J. King, and G. Jones, Varve calibrated records of carbonate and organic carbon accumulation over the last 2000 years in the Black Sea, Global Biogeochem. Cycles, 8, 195-217, 1994.

Beier, J., S. G. Wakeham, C. H. Pilskaln, and $S$. Honjo, Enrichment in saturated compounds of Black Sea interfacial sediment, Nature, 351, 642-644, 1991.

Brewer, $P . G$., Hydrographic data from cruise no. 49 of the RN Atlantis to the Black Sea, WHOI-7I-65 Tech. Rep., Woods Hole Oceanogr. Inst., Woods Hole, Mass., 1971.

Calvert, S. E., Oceanographic controls on the accumulation of organic matter in marine sediments, in Marine Petroleum Source Rocks, edited by J. Brooks and A. Fleet, pp. 137-151, Blackwell Sci., Malden, Mass., 1987.

Calvert, S. E., and M. R. Fontugne, Stable carbon isotopic evidence for the origin of the organic matter in Holocene Black Sea sapropel, Chem. Geol., 66, 315-322, 1987.

Crusius, J., and R. F. Anderson, Inconsistencies in accumulation rates of Black Sea sediments inferred from records of laminae and ${ }^{210} \mathrm{~Pb}$, Paleoceanography, 7, 215-227, 1992.

Degens, E. T., and D. A. Ross, Chronology of the Black Sea over the last 25,000 years, Chem. Geol., 10, 1-16, 1972.

Degens, E. T., and D. A. Ross (Eds.), The Black Sea: Geology, Chemistry, and Biology, Mem. Am. Assoc. Pet. Geol., 20, 633 pp, 1974.

Degens, E. T., P. Stoffers, S. Golubic, and M. D. Dickman, Varve chronology: Estimated rates of sedimentation in the Black Sea Deep Basin, Initial Rep. Deep Sea Drill. Project, 42B, 499-508, 1978.

Diercks, A.-R., and V. L. Asper, In situ settling speeds of marine snow aggregates below the mixed layer: Black Sea and Gulf of Mexico, Deep Sea Res., Part I, 44, 385398, 1997.
Deuser, W. G., Carbon-13 in Black Sea waters and implications for the origin of hydrogen sulfide, Science, 168, 1575-1577, 1970.

Deuser, W. G., Evolution of anoxic conditions in Black Sea during Holocene, in The Black Sea: Geology, Chemistry, and Biol$o g y$, edited by E. T. Degens and D. A. Ross, Mem. Am. Assoc. Pet. Geol., 20, 133-136, 1974.

Eggimen, D. W., F. T. Manheim, and P. R. Betzer, Dissolution and analysis of amorphous silica in marine sediments, $J$. Sediment. Petrol., 50, 215-225, 1980.

Hay, B. J., Sediment accumulation in the central western Black Sea over the past 5100 years, Paleoceanography, 3, 491-508, 1988

Hay, B. J., and S. Honjo, Particle deposition in the Present and Holocene Black Sea, Oceanography, 2, 26-31, 1989.

Hay, B. J., S. Honjo, S. Kempe, V. A. Ittekot, E. T. Degens, T. Konuk, and E. Izdar, Interannual variability in particle flux in the southwestern Black Sea, Deep Sea Res., Part I, 37, 911-928, 1990. 
Hay, B. J., M. A. Arthur, W. E. Dean, E. D. Neff, and S. Honjo, Sediment deposition in the late Holocene abyssal Black Sea with climatic and chronological implications, Deep Sea Res., Part I, 38, suppl. 2, 1211$1235,1991$.

Honjo, S., B. J. Hay, and members of the Shipboard Party, Temporal and spatial variability in sedimentation in the Black Sea: Cruise Report, R/V Knorr 134-8, Black Sea Leg 1, April 16 - May 7, 1988, WHOI-88-35 Tech. Rep., Woods Hole Oceanogr. Inst., Woods Hole, Mass., 1988.

Izdar, E. and J.W. Murray (Eds.), Black Sea Oceanography, 487 pp., Kluwer Acad., Norwell, Mass., 1991.

Jannasch, H. W., Microbial processes in the Black Sea water column and top sediment: An overview, in Black Sea Oceanography, edited by E. Izdar and J. W. Murray, pp. 271-286, Kluwer Acad., Norwell, Mass., 1991.

Jannasch, H. W., H. G. Tupper, and J. H. Tuttle, Microbial sulfur cycle in Black Sea, Mem. Am. Assoc. Pet. Geol., 20, 419-425, 1974

Jones, G. A., and A. R. Gagnon, Radiocarbon chronology of Black Sea sediments, Deep Sea Res., Part I, 41, 531-557, 1994.

Karl, D. M., Distribution, abundance, and metabolic states of microorganisms in the water column and sediments of the Black Sea, Limnol. Oceanogr., 23, 936-949, 1978 .

Karl, D. M., and G. A. Knauer, Microbial production and particle flux in the upper $350 \mathrm{~m}$ of the Black Sea, Deep Sea Res., Part I, 38, suppl. 2, 921-942, 1991.

Kemp, A. E. S., Sedimentary fabrics and variation in lamination style in Peru continental margin upwelling sediments, Proc. Ocean Drill. Program Sci. Results, 112, 43-58, 1990.

Krinsley, D. H., K. Pye, and A. T. Kearsley, Application of backscattered electron microscopy in shale petrology, Geol. Mag., J20, 109-114, 1983.

Lane-Serff, G. F., E. J. Rohling, H. L. Bryden, and $H$. Charnock, Postglacial connection of the Black Sea to the Mediterranean and its relation to the timing of sapropel formation, Paleoceanography, 12, 169-174, 1997.

Limonov, A. F., J. M. Woodside, and M. K. Ivanov, Mud volcanism in the Mediterranean and Black Seas and shallow structure of the Eratosthenes Seamount, UNESCO Rep. Mar. Sci., 64, 173 pp., 1994.

Lyons, T. W., Upper Holocene sediments of the Black Sea: Summary of Leg 4 box cores (1988 Black Sea Oceanographic Expedition), in Black Sea Oceanography, edited by E. Izdar and J. W. Murray, pp. 40I441, Kluwer Acad., Norwell, Mass., 1991.

Macquaker, J. H. S. and R. L. Gawthorpe, Mudstone lithofacies in the Kimmeridge Clay Formation, Wessex basin, southern England: Implications for the origin and controls of the distribution of mudstones, J. Sediment. Petrol., 63, 1129-1143, 1993.

Manheim, F. T., and K. M. Chan, Interstitial waters of Black Sea sediments: New data and review, Mem. Am. Assoc. Pet Geol. 20, 155-173, 1974.

Millero, F. J., The oxidation of $\mathrm{H}_{2} \mathrm{O}$ with $\mathrm{O}_{2}$ in the Black Sea, in Black Sea Oceanography, edited by E. Izdar and J. W. Murray, pp. 205-228, Kluwer Acad., Norwell Mass., 1991.

Moore, W., and D. O'Neill, Radionuclide distributions in recent Black Sea sediments, in Black Sea Oceanography, edited by E. Izdar and J. W. Murray, pp. 257-270, Kluwer Acad., Norwell, Mass., 1991.

Muramoto, J., S. Honjo, B. Fry, B. J. Hay, R. W. Howarth, and J. L. Cisne, Sulfur, iron and organic carbon fluxes in the Black Sea: sulfur isotopic evidence for the origin of sulfur fluxes, Deep Sea Res., Part 1,38 , suppl. 2, 1151-1187, 1991 .

Murray, J. W., H. W. Jannasch, S. Honjo, R. F. Anderson, W. S. Reeburgh, Z. Top, E. E. Friederich, L. A. Codispoti and E. Izdar, Unexpected changes in the oxic/anoxic interface in the Black Sea, Nature, 338,411 $413,1989$.

Murray, J. W.,Z. Top, and E. Ozsov, Temperature and salinity distributions in the Black Sea, Deep-Sea Res., Part I, 38, suppl. 2, $663-689,1991$.

Ozsoy, E., Z. Top, G. White, and J. M. Murray, Double diffusive intrusions, mixing and deep sea convection processes in the Black Sea, in Black Sea Oceanography, edited by E. Izdar and J. W. Murray, pp 14-42, Kluwer Acad, Norwell, Mass., 1991.

Pike, J, and A. E. S. Kemp, Preparation and analysis techniques for studies of laminated sediments, in Paleoclimatology and Paleoceanography From Laminated Sediments, edited by A. E. S. Kemp, Geol. Soc. Spec. Publ. II6, 37-48, 1996.

Pike, J., and A. E. S. Kemp, Early Holocene decadal-scale ocean variability recorded in Gulf of California laminated sediments, Paleoceanography, 12, 227-238, 1997.

Pilskaln, C. H., Biogenic aggregate sedimentation in the Black Sea Basin, in Black Sea
Oceanography, edited by E. Izdar and J. W. Murray, pp. 293-306, Kluwer Acad., Nowell, Mass., 1991.

Pye, K., and D. H. Krinsley, Petrographic examination of sedimentary rocks in the SEM using backscattered electron detectors, J. Sediment. Petrol., 54, 877-888, 1984.

Ross, D. A., and E. T. Degens, Recent sediments of Black Sea, in The Black Sea- Geology, Chemistry and Biology, edited by $\mathrm{E}$. T. Degens and D. A Ross, pp. 183-199, Mem Am. Assoc. Pet. Geol., 20, 1974.

Ryan, W. B. F., W. C. Pitman III, C. O. Major, K. Shimkus, V. Moskalenko, G. A. Jones, $P$. Dimitrov, N. Goruer, M. Sakinc, and H. Yuece, An abrupt drowning of the Black Sea shelf, Mar. Geol., 138, 119-126, 1997.

Shimkus, K. M., and E. S. Trimonis, Modern sedimentation in Black Sea, in The Black Se:- Geology, Chemistry, and Biology, edited by E. T. Degens and D. A Ross, pp. 249-278, Mem. Am. Assoc. Pet. Geol., 20 , 1974.

Shimkus, K. M., V. V. Mukhina, and E. S Trimonis, On the role of diatoms in the Quaternary sedimentation in the Black Sea, Oceanology, 13, 882-887, 1973.

Sorokin, Y. I., The Black Sea, in Estuartes and Enclosed Seas, Ecosystems of the World, edited by B. Ketchum, pp. 253-292, Elsevier Sci., New York, 1983.

Vine, A. C., Bottom photographs of Black Sea, in The Black Sea: Geology, Chemistry and Biology, edited by E. T. Degens and D. A. Ross, pp. 338-346, Mem. Am. Assoc. Pet. Geol., 20, 1974.

Wakeham, S.'G., and J. A. Beier, Fatty acid and sterol biomarkers as indicators of particulate matter source and alteration processes in the Black Sea, Deep Sea Res. Part. I. 38, suppl. 2, 943-968, 1991.

Wilkin, R. T., M. A. Arthur, and W. E. Dean, History of water-column anoxia in the Black Sea indicated by pyrite framboid size distribution, Earth Planet Sci. Lett. 148, 517-525, 1997.

J. Pike, Department of earth Sciences, University of Wales, P.O. Box 914, Cardiff CF1 3YE, Wales, UK.

C. H. Pilskaln, School of Marine Sciences, 5741 Libby Hall, University of Maine, Orono, ME 04469 (pilskaln(omaine.edu)

(Received October 13, 1999; revised June 16,2000 ; accepted June 28,2000 .) 